\title{
Disruption of Rat Forebrain Development by Glucocorticoids: Critical Perinatal Periods for Effects on Neural Cell Acquisition and on Cell Signaling Cascades Mediating Noradrenergic and Cholinergic Neurotransmitter/ Neurotrophic Responses
}

\author{
Marisa L Kreider', Justin E Aldridge', Mandy M Cousins', Colleen A Oliver', Frederic J Seidler' and \\ Theodore A Slotkin*, I
}

'Department of Pharmacology and Cancer Biology, Duke University Medical Center, Durham, NC, USA

\begin{abstract}
Glucocorticoids are the consensus treatment for the prevention of respiratory distress in preterm infants, but there is evidence for increased incidence of neurodevelopmental disorders as a result of their administration. We administered dexamethasone (Dex) to developing rats at doses below or within the range of those used clinically, evaluating the effects on forebrain development with exposure in three different stages: gestational days 17-19, postnatal days 1-3, or postnatal days 7-9. At 24h after the last dose, we evaluated biomarkers of neural cell acquisition and growth, synaptic development, neurotransmitter receptor expression, and synaptic signaling mediated by adenylyl cyclase (AC). Dex impaired the acquisition of neural cells, with a peak effect when given in the immediate postnatal period. In association with this defect, Dex also elicited biphasic effects on cholinergic presynaptic development, promoting synaptic maturation at a dose $(0.05 \mathrm{mg} / \mathrm{kg})$ well below those used therapeutically, whereas the effect was diminished or lost when doses were increased to 0.2 or $0.8 \mathrm{mg} / \mathrm{kg}$. Dex given postnatally also disrupted the expression of adrenergic receptors known to participate in neurotrophic modeling of the developing brain and evoked massive induction of AC activity. As a consequence, disparate receptor inputs all produced cyclic AMP overproduction, a likely contributor to disrupted patterns of cell replication, differentiation, and apoptosis. Superimposed on the heterologous AC induction, Dex impaired specific receptor-mediated cholinergic and adrenergic signals. These results indicate that, during a critical developmental period, Dex administration leads to widespread interference with forebrain development, likely contributing to eventual, adverse neurobehavioral outcomes.
\end{abstract}

Neuropsychopharmacology (2005) 30, I84I- | 855. doi: I0.1038/sj.npp. I 300743; published online 20 April 2005

Keywords: acetylcholine systems; adenylyl cyclase signaling; antenatal glucocorticoids; brain development; dexamethasone; noradrenergic systems; preterm delivery

\section{INTRODUCTION}

For over a decade, synthetic glucocorticoids like dexamethasone (Dex) have been the consensus treatment for the prevention of neonatal respiratory distress in preterm birth (Gilstrap et al, 1994). Such therapy has saved thousands of lives and enabled survival of very preterm infants, and antenatal glucocorticoid use currently encompasses nearly

\footnotetext{
*Correspondence: Dr TA Slotkin, Department of Pharmacology and Cancer Biology, Duke University Medical Center, Box 3813 DUMC, Room C162, LSRC Building, Research Drive, Durham, NC, USA, Tel: + |9196818015, Fax: + I9196848197, E-mail: t.slotkin@duke.edu Received 8 February 2005; revised 10 March 2005; accepted II March 2005

Online publication: 14 March 2005 at http://www.acnp.org/citations/ NPP03 | 40505008 I/default.pdf
}

$10 \%$ of all US pregnancies (Matthews et al, 2002). Accordingly, hundreds of thousands of infants receive glucocorticoid treatment whose mothers do not end up delivering prematurely or who might not have developed respiratory distress. Even within the target population, the use of multiple glucocorticoid courses has become a common practice (Dammann and Matthews, 2001), and may even become a recommended treatment (Crowther and Harding, 2003), despite the fact that the original recommendation was for a single course (Gilstrap et al, 1994). It is increasingly suspected that excessive glucocorticoid treatment leads to life-long abnormalities of metabolic, cardiovascular, and behavioral function (Barrington, 2001; Seckl, 2001; Shinwell et al, 2000; Trautman et al, 1995; Yeh et al, 2004). However, epidemiologic studies are confounded by the comorbidities and multiple pharmacologic interven- 
tions inherent to the population born prematurely or undergoing therapies for preterm labor. In this regard, animal models become especially important to establish a cause-and-effect relationship between early glucocorticoid treatment and subsequent anomalies.

The adverse effects of glucocorticoids on brain development and behavioral outcomes have been well characterized but to date, most studies have focused on treatments that lie well above the dose range typical of therapeutic interventions in preterm infants, often sufficient to produce persistent stunting of somatic growth and outright cerebral atrophy and endocrine disruption (Bohn, 1984; Fuxe et al, 1994, 1996; Gilad et al, 1998; Gould et al, 1997; Maccari et al, 2003; Matthews, 2000; Matthews et al, 2002; McEwen, 1992; Meaney et al, 1996; Weinstock, 2001; Welberg and Seckl, 2001). Models incorporating stress as a mechanism for increasing circulating glucocorticoids have also proven useful in characterizing neurodevelopmental defects, especially those influencing hypothalamus-pituitary-adrenal axis function (Dean et al, 2001; Felszeghy et al, 2000; Muneoka et al, 1997), but of course, these involve contributions of factors beyond glucocorticoids alone. Nevertheless, several recent studies in rats suggest that glucocorticoids, in doses commensurate with their use in preterm infants, produces lasting alterations in performance, encompassing motor activity, social behaviors, learning, and memory (Benesová and Pavlík, 1989; Kamphuis et al, 2003, 2004; Kreider et al, 2005), resembling some of the changes elicited by prenatal stress (Bowman et al, 2004). The current study establishes a cause-and-effect relationship between perinatal Dex treatment in rats and adverse effects on brain development by exploring doses well below $(0.05 \mathrm{mg} / \mathrm{kg})$ or within the therapeutic range $(0.2$ or $0.8 \mathrm{mg} / \mathrm{kg}$ ), encompassing three different treatment windows that correspond to human neurodevelopment in the second to early third trimester (Dobbing and Sands, 1979; Rodier, 1988), the period in which glucocorticoids are most likely to be administered (Gilstrap et al, 1994): gestational days (GD) 17-19, postnatal days (PN) 1-3 and PN7-9. We evaluated developmental consequences in the forebrain $24 \mathrm{~h}$ after the last treatment. The forebrain contains the hippocampus, neocortex, and corpus striatum, regions that are highly enriched in glucocorticoid receptors and that are putative targets for developmental disruption by Dex (Kawata et al, 1998; Kitraki et al, 1996; Meaney et al, 1993; Owen and Matthews, 2003). We focused on families of biomarkers that characterize different mechanisms likely to contribute to adverse outcomes. First, we assessed the impact on neural cell acquisition and growth by measurements of DNA and cell protein fractions. Each neural cell contains only a single nucleus (Winick and Noble, 1965), so that the DNA content (amount of DNA in each brain region) reflects the total number of cells, and the DNA concentration (DNA per unit tissue weight) reflects the cell packing density (Bell et al, 1987; Slotkin et al, 1984; Winick and Noble, 1965). We also assessed the complement of cell proteins related to differentiation as opposed to cell numbers. As neurons specialize, they enlarge and develop axonal and dendritic projections. The ratio of total protein/ DNA thus rises with the expansion of the cell (Qiao et al, 2003, 2004; Slotkin et al, 2005). The development of neuritic projections necessitates a rise in the contribution of membrane proteins relative to other cell proteins, and accordingly, we also assessed the membrane protein concentration and the ratio of membrane proteins to total cell proteins.

The second set of biomarkers focused on the potential impact on two specific neurotransmitter systems, acetylcholine and norepinephrine. Both of these transmitters play a critical role as trophic factors in development of the forebrain (Dreyfus, 1998; Hohmann, 2003; Hohmann and Berger-Sweeney, 1998; Lauder and Schambra, 1999; Whitaker-Azmitia, 1991) and are likely targets for developmental effects of glucocorticoids ( $\mathrm{Hu}$ et al, 1996; Muneoka et al, 1997; Reznikov et al, 2004; Shi et al, 1998; Slotkin et al, 1982; Zahalka et al, 1993b). We evaluated choline acetyltransferase (ChAT) activity and the binding of $\left[{ }^{3} \mathrm{H}\right]$ hemicholinium-3 (HC3) to the high-affinity presynaptic choline transporter. ChAT is the enzyme responsible for acetylcholine biosynthesis and the choline transporter regulates the rate-limiting step, availability of intracellular choline (Klemm and Kuhar, 1979; Simon et al, 1976). The transporter is overexpressed in the developing brain and is regulated by glucocorticoids (Zahalka et al, 1993a, b). We also characterized three neurotransmitter receptor-binding sites, $\beta$-adrenoceptor ( $\beta \mathrm{AR}), \alpha_{2}$-adrenoceptor $\left(\alpha_{2} \mathrm{AR}\right)$, and $\mathrm{m}_{2}$-muscarinic acetylcholine receptor $\left(\mathrm{m}_{2} \mathrm{AChR}\right)$. Each receptor has been implicated in the control of neural cell acquisition and differentiation (Duncan et al, 1990; Garofolo et al, 2003; Hodges-Savola et al, 1996; Kreider et al, 2004; Lidow and Rakic, 1995; Slotkin et al, 1988; Zhou et al, 2004) and, like the HC3-binding site, the $\beta \mathrm{AR}$ and $\alpha_{2} \mathrm{AR}$ are overexpressed in the fetal brain (Kreider et al, 2004; Lidow et al, 1991; Slotkin et al, 1994b; Zahalka et al, 1993a). Notably, glucocorticoids have a direct effect on $\beta$ AR expression (Davies and Lefkowitz, 1984; Tseng et al, 2002). Finally, we assessed the impact on cell signaling mediated by adenylyl cyclase (AC), the pathway that regulates production of the second messenger, cyclic AMP, a universal signal regulating replication and differentiation of virtually all eucaryotic and procaryotic cells. In addition to assessing basal AC activity, we evaluated the enzymatic response mediated by the three neurotransmitter receptors, as well as the relative coupling of receptors in comparison to glucocorticoid effects on total AC activity. The latter is especially important in light of our earlier report showing that, during development, glucocorticoids can enhance total AC activity, thus increasing cyclic AMP production in response to disparate receptor inputs (Slotkin et al, 1994a).

\section{METHODS}

\section{Animal Treatments}

All studies were performed in accordance with the Declaration of Helsinki and with the Guide for the Care and Use of Laboratory Animals as adopted and promulgated by the National Institutes of Health. Timed-pregnant Sprague-Dawley rats were housed individually and given free access to food and water. For studies of gestational Dex exposure, dams received daily subcutaneous injections of Dex phosphate $(0.05,0.2$, or $0.8 \mathrm{mg} / \mathrm{kg})$ on GD17-19, whereas controls received equivalent volumes $(1 \mathrm{ml} / \mathrm{kg})$ of isotonic saline vehicle. On GD20, $24 \mathrm{~h}$ after the last Dex 
treatment, dams were decapitated and fetuses were counted, weighed, and decapitated; the fetal forebrain was then dissected by making a cut rostral to the thalamus. This dissection, which follows the natural planes of the fetal and neonatal rat brain, includes the corpus striatum, hippocampal formation, and neocortex within the area designated as 'forebrain.' Forebrain samples from four fetuses derived from the same dam were then frozen together in liquid nitrogen and stored at $-45^{\circ} \mathrm{C}$. For studies of the effects of postnatal Dex treatment $(0,0.05,0.2$, or $0.8 \mathrm{mg} / \mathrm{kg}$ given on PN1-3 or PN7-9), pups were randomized at birth and redistributed to the nursing dams with litter size maintained at 10 to ensure standardized nutrition, with randomization repeated within treatment groups for each daily injection. At $24 \mathrm{~h}$ after the last injection, animals were selected from each litter and forebrain samples prepared combining two animals per litter on PN4 and one per litter on PN10. Group sizes consisted of six animals per treatment for determinations on GD20 (sex not determined), and six males and six females for each treatment for those on PN4 and PN10. To ensure that the treatment effects were unbiased by maternal differences, each dam or litter contributed only a single sample.

\section{Biomarkers of Neural Cell Development}

Tissues were thawed in 19 volumes of ice-cold $10 \mathrm{mM}$ sodium-potassium phosphate buffer $(\mathrm{pH} 7.4)$ and homogenized with a Polytron (Brinkmann Instruments, Westbury, NY). DNA was assessed with a modified (Trauth et al, 2000) fluorescent dye-binding method (Labarca and Piagen, 1980). Aliquots were diluted in $50 \mathrm{mM}$ sodium phosphate, $2 \mathrm{M} \mathrm{NaCl}, 2 \mathrm{mM}$ EDTA (pH 7.4) and sonicated briefly (Virsonic Cell Disrupter, Virtis, Gardiner, NY). Hoechst 33258 was added to a final concentration of $1 \mu \mathrm{g} / \mathrm{ml}$. Samples were then read in a spectrofluorometer using an excitation wavelength of $356 \mathrm{~nm}$ and an emission wavelength of $458 \mathrm{~nm}$, and were quantitated using standards of purified DNA. The total concentration of tissue proteins was assayed from the original homogenate spectrophotometrically with bicinchoninic acid (Smith et al, 1985); in addition, we assessed the concentration of membrane proteins from the membrane preparations used for radioligand binding, as described below. For calculation of the ratio of membrane/total protein, the membrane protein value was averaged across the different membrane preparations.

\section{Cholinergic Presynaptic Biomarkers}

Aliquots of the original tissue homogenate were assayed in duplicate for ChAT using established procedures (Lau et al, 1988; Qiao et al, 2003, 2004). Each tube contained final concentrations of $60 \mathrm{mM}$ sodium phosphate ( $\mathrm{pH} 7.9$ ), $200 \mathrm{mM} \mathrm{NaCl}, 20 \mathrm{mM}$ choline chloride, $17 \mathrm{mM} \mathrm{MgCl}$, $1 \mathrm{mM}$ EDTA, $0.2 \%$ Triton X-100, $0.12 \mathrm{mM}$ physostigmine, $0.6 \mathrm{mg} / \mathrm{ml}$ bovine serum albumin, and $50 \mu \mathrm{M}\left[{ }^{14} \mathrm{C}\right]$ acetylcoenzyme A. Blanks contained homogenization buffer instead of the tissue homogenate. Samples were preincubated for $15 \mathrm{~min}$ on ice, transferred to a $37^{\circ} \mathrm{C}$ water bath for $30 \mathrm{~min}$, and the reaction was terminated by placing the samples on ice. Labeled acetylcholine was then extracted, counted and the activity determined relative to tissue protein (Smith et al, 1985). Preliminary determinations established that enzyme activity was linear with time and tissue concentration under these conditions.

For measurements of HC3 binding, an aliquot of the same tissue homogenate was sedimented at $40000 \mathrm{~g}$ for $15 \mathrm{~min}$ and the supernatant solution was discarded. The membrane pellet was resuspended (Polytron) in the original volume of buffer, resedimented, and the resultant pellet was resuspended using a smooth glass homogenizer fitted with a Teflon pestle, in $10 \mathrm{mM}$ sodium-potassium phosphate buffer ( $\mathrm{pH}$ 7.4) containing $150 \mathrm{mM} \mathrm{NaCl}$. Radioligand binding was evaluated with $2 \mathrm{nM}\left[{ }^{3} \mathrm{H}\right] \mathrm{HC} 3$ (Vickroy et al, 1984), with incubation for $20 \mathrm{~min}$ at room temperature, followed by rapid vacuum filtration onto glass fiber filters (presoaked for $30 \mathrm{~min}$ with $0.1 \%$ polyethyleneimine in buffer). The nonspecific component was defined as radioligand binding in the presence of an excess concentration of unlabeled $\mathrm{HC} 3(10 \mu \mathrm{M})$ and binding values were expressed relative to membrane protein. Nonspecific binding averaged $35 \%$ on GD20 but rose to $65 \%$ postnatally.

\section{Neurotransmitter Receptor Binding}

Receptor binding was assessed in aliquots of the same original homogenate in sodium-potassium phosphate buffer as already described for the HC3 binding determinations. After the first sedimentation, we followed two different procedures for subsequent resuspension, washing, resedimentation, and final suspension. For $\beta \mathrm{AR}$ binding, $\alpha_{2} \mathrm{AR}$ binding, and AC activity, the buffer consisted of $125 \mathrm{mM}$ sucrose, $6 \mathrm{mM} \mathrm{MgCl}_{2}$, $50 \mathrm{mM}$ Tris- $\mathrm{HCl}$ ( $\mathrm{pH} 7.5$ ), whereas for $\mathrm{m}_{2} \mathrm{AChR}$ binding, the same sodium-phosphate buffer was used as for HC3. To evaluate $\beta$ AR binding, aliquots of membrane preparation were incubated with $\left[{ }^{125} \mathrm{I}\right]$ iodopindolol (final concentration $67 \mathrm{pM}$ ), in $145 \mathrm{mM}$ $\mathrm{NaCl}, 2 \mathrm{mM} \mathrm{MgCl}$, $1 \mathrm{mM} \mathrm{Na}$ ascorbate, $20 \mathrm{mM}$ Tris ( $\mathrm{pH}$ 7.5), for $20 \mathrm{~min}$ at room temperature in a total volume of $250 \mu \mathrm{l}$. Displacement of nonspecific binding was evaluated with $100 \mu \mathrm{M} d, l$-isoproterenol, comprising $30 \%$ of total binding on GD20 and $10 \%$ at postnatal age points. For $\alpha_{2} \mathrm{AR}$ binding, the ligand was $2.5 \mathrm{nM}\left[{ }^{3} \mathrm{H}\right]$ rauwolscine, which was incubated for $20 \mathrm{~min}$ at room temperature, with membrane preparation and final concentrations of $10 \mathrm{mM} \mathrm{MgCl}_{2}$ and $50 \mathrm{mM}$ Tris ( $\mathrm{pH}$. 7.5). Nonspecific binding was evaluated with $10 \mu \mathrm{M}$ phentolamine, and constituted $30 \%$ of the total. Binding to $\mathrm{m}_{2} \mathrm{AChRs}$ was evaluated with $1 \mathrm{nM}$ $\left[{ }^{3} \mathrm{H}\right]$ AFDX384, incubated for $60 \mathrm{~min}$ at room temperature in $10 \mathrm{mM}$ sodium phosphate $(\mathrm{pH} 7.4)$, and nonspecific binding was evaluated with $1 \mu \mathrm{M}$ atropine; nonspecific binding was $25 \%$ of the total on GD20, falling to $10 \%$ by PN10.

\section{AC Activity}

AC assessments were conducted by standard techniques published previously (Auman et al, 2000, 2001a; Zeiders et al, 1997, 1999a). Briefly, aliquots of the same membrane preparation used for the $\beta \mathrm{AR}$-binding assays were incubated for $10 \mathrm{~min}$ at $30^{\circ} \mathrm{C}$ with final concentrations of $100 \mathrm{mM}$ Tris- $\mathrm{HCl}$ ( $\mathrm{pH} 7.4$ ), $10 \mathrm{mM}$ theophylline, $1 \mathrm{mM}$ ATP, $2 \mathrm{mM} \mathrm{MgCl} 2,1 \mathrm{mg} / \mathrm{ml}$ bovine serum albumin, and a creatine 
phosphokinase-ATP-regenerating system consisting of $10 \mathrm{mM}$ sodium phosphocreatine and $8 \mathrm{IU} / \mathrm{ml}$ phosphocreatine kinase, with $10 \mu \mathrm{M}$ GTP in a total volume of $250 \mu \mathrm{l}$. The enzymatic reaction was stopped by placing the samples in a $90-100^{\circ} \mathrm{C}$ water bath for $5 \mathrm{~min}$, followed by sedimentation at $3000 \mathrm{~g}$ for $15 \mathrm{~min}$, and the supernatant solution was assayed for cyclic AMP using radioimmunoassay kits. Preliminary experiments showed that the enzymatic reaction was linear well beyond the assay period and was linear with membrane protein concentration; concentrations of cofactors were optimal and, in particular, higher concentrations of GTP produced no further augmentation of activity.

$\mathrm{AC}$ activity was evaluated in several different ways. First, we measured basal AC activity without addition of any stimulants. Next, we compared the responses of two direct AC stimulants, forskolin $(100 \mu \mathrm{M})$ and $\mathrm{Mn}^{2+}(10 \mathrm{mM})$; these discriminate the effects of $\mathrm{G}_{\mathrm{s}}-\mathrm{AC}$ association, which selectively enhances the forskolin response (Limbird and Macmillan, 1981; Seamon and Daly, 1986), as well as allowing for detection of shifts in the AC isoform (Zeiders et al, 1999b). Finally, we compared the responses to activation of different neurotransmitter receptor stimulants, using $100 \mu \mathrm{M}$ isoproterenol ( $\beta \mathrm{AR}$ agonist), $100 \mu \mathrm{M}$ clonidine $\left(\alpha_{2} \mathrm{AR}\right.$ agonist), or $100 \mu \mathrm{M}$ carbachol $\left(\mathrm{m}_{2} \mathrm{AChR}\right.$ agonist). Since the latter two act in part on the inhibitory G-protein, $G_{i}$, their assessments were conducted in samples that were activated by addition of forskolin (Auman et al, 2001a,b; Garofolo et al, 2002; Slotkin et al, 1991b). These concentrations of each stimulant produce maximal responses, as assessed in earlier studies (Auman et al, 2000, 2001a; Zeiders et al, 1997, 1999a).

\section{Data Analysis}

Data are presented as means and standard errors. Differences between groups were first assessed by a global analysis of variance (ANOVA) (data log-transformed because of heterogeneous variance), incorporating all factors: drug treatment, treatment regimen, and sex (with the exception of GD17-19 Dex treatment, as already noted). This initial test was conducted across related measurements (considered as repeated measures, since they were all derived from the same homogenate) corresponding to each index class: cell development biomarkers (DNA and protein fractions), cholinergic presynaptic markers (ChAT, HC3), receptor binding $(\beta \mathrm{AR}$, $\alpha_{2} \mathrm{AR}, \mathrm{m}_{2} \mathrm{AChR}$ ), and the multiple AC measures. Depending on the treatment interactions obtained in the global tests, data were then subdivided for lower order ANOVAs, followed where appropriate, by Fisher's Protected Least Significant Difference to establish effects comparing individual groups. Significance for main treatment effects was assumed at $p<0.05$; however, for interactions at $p<0.1$, we also examined whether lower order main effects were detectable after subdivision of the interactive variables (Snedecor and Cochran, 1967). For convenience, some data are presented as the percentage change from control values; however, statistical evaluations were always carried out on the original data. For reference, control values are given in Table 1.

\section{Materials}

Animals were purchased from Charles River Laboratories, Raleigh, NC. $\left[{ }^{14} \mathrm{C}\right]$ Acetyl-CoA (specific activity $44 \mathrm{mCi} / \mathrm{mmol}$,

Table I Control Values

\begin{tabular}{|c|c|c|c|c|c|}
\hline \multirow[b]{2}{*}{ Measure } & \multirow[b]{2}{*}{ GD20 } & \multicolumn{2}{|c|}{ PN4 } & \multicolumn{2}{|c|}{ PNIO } \\
\hline & & Male & Female & Male & Female \\
\hline Forebrain wt (mg) & $74 \pm 2$ & $256 \pm 3$ & $244 \pm 5$ & $608 \pm 13$ & $591 \pm 10$ \\
\hline DNA concentration (mg/g) & $4.4 \pm 0.1$ & $2.16 \pm 0.02$ & $2.23 \pm 0.01 *$ & $1.50 \pm 0.01$ & $1.51 \pm 0.02$ \\
\hline Membrane/total protein $(\mu \mathrm{g} / \mu \mathrm{g})$ & $0.21 \pm 0.01$ & $0.237 \pm 0.007$ & $0.242 \pm 0.008$ & $0.321 \pm 0.013$ & $0.281 \pm 0.009 *$ \\
\hline ChAT activity (pmol/mg protein/min) & $52 \pm 2$ & $66 \pm 1$ & $70 \pm 2$ & $246 \pm 6$ & $254 \pm 3$ \\
\hline HC3 binding (fmol/mg protein) & $11.5 \pm 0.7$ & $8.7 \pm 1.3$ & $8.6 \pm 1.8$ & $9.2 \pm 0.7$ & $11.0 \pm 0.8$ \\
\hline$\beta A R$ binding (fmol/mg protein) & $12.2 \pm 0.8$ & $5.8 \pm 0.3$ & $5.2 \pm 0.5$ & $7.0 \pm 0.8$ & $9.2 \pm 0.5$ \\
\hline$\alpha_{2} A R$ binding (fmol/mg protein) & $213 \pm 29$ & $74 \pm 10$ & $53 \pm 5$ & $48 \pm 4$ & $50 \pm 3$ \\
\hline Basal & $132 \pm 7$ & $214 \pm 7$ & $212 \pm 11$ & $130 \pm 19$ & $145 \pm 12$ \\
\hline Isoproterenol & $146 \pm 7$ & $235 \pm 9$ & $233 \pm 8$ & $142 \pm 18$ & $139 \pm 13$ \\
\hline $\mathrm{Mn}^{2+}$ & $1322 \pm 58$ & $1736 \pm 143$ & $2004 \pm 144$ & $1382 \pm 178$ & $1813 \pm 63^{*}$ \\
\hline Forskolin & $590 \pm 26$ & $872 \pm 21$ & $940 \pm 26 *$ & $531 \pm 100$ & $702 \pm 55$ \\
\hline Forskolin and clonidine & $588 \pm 40$ & $707 \pm 46$ & $893 \pm 35 *$ & $630 \pm 96$ & $772 \pm 52$ \\
\hline Forskolin and carbachol & $575 \pm 40$ & $784 \pm 35$ & $849 \pm 39$ & $499 \pm 67$ & $680 \pm 50 *$ \\
\hline
\end{tabular}

*Significant difference between males and females. 
diluted with unlabeled compound to $6.7 \mathrm{mCi} / \mathrm{mmol})$, $\left[{ }^{3} \mathrm{H}\right] \mathrm{HC} 3(161 \mathrm{Ci} / \mathrm{mmol}),\left[{ }^{125} \mathrm{I}\right]$ iodopindolol $(2200 \mathrm{Ci} / \mathrm{mmol})$, $\left[{ }^{3} \mathrm{H}\right]$ rauwolscine $(78 \mathrm{Ci} / \mathrm{mmol})$, and $\left[{ }^{3} \mathrm{H}\right]$ AFDX384 $(133 \mathrm{Ci} /$ mmol) were obtained from Perkin-Elmer Life Sciences (Boston, MA). Cyclic AMP radioimmunoassay kits were purchased from GE Healthcare (Piscataway, NJ). Sigma Chemical Co. (St Louis, MO) was the source for all other reagents.

\section{RESULTS}

In control rat forebrain, the DNA concentration fell progressively from GD20 through PN10 whereas the DNA content rose (Table 1), commensurate with the normal ontogenetic decrease in cell packing density and the acquisition of new cells accompanying the brain growth spurt (Dobbing and Sands, 1979; Qiao et al, 2003; Rodier, 1988). Cell enlargement and neuritic extension also were demonstrable in the rise in protein/DNA and membrane/ total protein ratios and similar increments were seen in ChAT activity and $\mathrm{m}_{2} \mathrm{AChR}$ binding. In contrast, $\beta \mathrm{AR}$, $\alpha_{2} \mathrm{AR}$, and HC3-binding sites exhibited fetal overexpression, with higher values on GD20 as compared to PN4, in keeping with earlier results (Kreider et al, 2004; Lidow et al, 1991; Slotkin et al, 1994b; Zahalka et al, 1993a). Isoproterenol evoked a small (10\%) but statistically significant increase in AC activity $(p<0.002)$, as would be expected from the relatively minor proportion of total enzyme activity that is linked to $\beta$ ARs. Accordingly, the response to direct activation of all AC molecules was far more substantial: a 10-fold increase for $\mathrm{Mn}^{2+}(p<0.0001)$ and a 4-5-fold increase for forskolin $(p<0.0001)$. There was no net response to the $\alpha_{2} \mathrm{AR}$ agonist, clonidine, on GD20 but significant inhibition ( $15 \%$ decrease, $p<0.01)$ was seen on PN4 and stimulation on PN10 (20\% increase, $p<0.007)$. Carbachol also evoked significant AC inhibition (10\% decrease, $p<0.002$ ) at PN4 but had little or no effect at other ages. There were only sporadic sex differences in any of the parameters.

In order to avoid type I statistical errors that might occur from repeated testing of the data sets, we first performed global ANOVAs on data groupings for each cluster of developmental characteristics: weights, cell development biomarkers, cholinergic presynaptic biomarkers, neurotransmitter receptor binding, and AC activity (Table 2). Each set of variables showed significant treatment differences that interacted with regimen (ie the different Dex treatment periods) and/or measure, indicating the need to separate the various measurements from each other and to examine the effects of the different Dex regimens separately. Accordingly, as described below, the data were subdivided by the two interactive variables and lower-order effects of treatment and treatment $\times$ sex interactions were re-examined. Where there was no treatment $\times$ sex interaction, sex was retained as a factor in the lower-order statistical analysis but the results for males and females were combined for presentation.

\section{Dex Treatment on GD17-19}

Maternal body weights at the end of Dex treatment on GD20 were not significantly different from control values: $340 \pm 16 \mathrm{~g}$ in controls, $332 \pm 13 \mathrm{~g}$ in the Dex $0.05 \mathrm{mg} / \mathrm{kg}$ group, $337 \pm 9 \mathrm{~g}$ in the Dex $0.2 \mathrm{mg} / \mathrm{kg}$ group, and $314 \pm 9 \mathrm{~g}$ in the Dex $0.8 \mathrm{mg} / \mathrm{kg}$ group. However, considering the weight gain during the period of Dex administration, even the lowest dose of Dex impaired maternal weight gain over the course from GD17 to GD20 (Figure 1a). Since the prepregnancy weights of the dams averaged $220 \mathrm{~g}$, only the group receiving the highest Dex dose actually showed a reduced weight gain of greater than $10 \%$ over the course of gestation. Despite these effects on the dam, there was no effect on fetal viability or on the number of fetuses (Figure 1a). Similarly, fetal body weights were unaffected on GD20 and even the highest Dex dose elicited only a small reduction in forebrain weight (Figure 1b); the same pattern was seen when whole brain weight was considered (data not shown). Across all the cell development biomarkers, Dex treatment at 0.05 or $0.2 \mathrm{mg} / \mathrm{kg}$ had no net effect but at $0.8 \mathrm{mg} / \mathrm{kg}$, there were significant overall deficits $(p<0.02)$. The overall reduction clearly represented the contributions of impaired DNA content (Figure 2a) and membrane/total protein (Figure $2 \mathrm{~b}$ ).

Table 2 Global ANOVA

\begin{tabular}{|c|c|c|c|c|c|}
\hline & $\begin{array}{c}\text { Body and forebrain } \\
\text { weight }\end{array}$ & $\begin{array}{l}\text { Cell development } \\
\text { biomarkers }^{\text {a }}\end{array}$ & $\begin{array}{c}\text { Cholinergic presynaptic } \\
\text { biomarkers }^{b}\end{array}$ & $\begin{array}{l}\text { Neurotransmitter } \\
\text { receptor binding }\end{array}$ & AC activity ${ }^{d}$ \\
\hline Treatment & $p<0.0001$ & $p<0.0001$ & $p<0.002$ & NS & $p<0.000$ \\
\hline Treatment $\times$ regimen & $p<0.0001$ & $p<0.03$ & $p<0.006$ & NS & $p<0.04$ \\
\hline Treatment $\times$ sex & NS & NS & NS & $p<0.0002$ & NS \\
\hline Treatment $\times$ measure & $p<0.0001$ & $p<0.0001$ & $p<0.0002$ & $p<0.005$ & $p<0.0008$ \\
\hline Treatment $\times$ regimen $\times$ measure & $p<0.04$ & $p<0.0009$ & $p<0.008$ & NS & $p<0.08$ \\
\hline Treatment $\times$ sex $\times$ measure & NS & NS & NS & $p<0.0001$ & $p<0.02$ \\
\hline Treatment $\times$ regimen $\times$ se $x \times$ measure & $p<0.07$ & NS & NS & NS & NS \\
\hline
\end{tabular}

NS, not significant.

${ }^{a}$ DNA concentration, DNA content, Total protein/DNA, membrane/total protein.

${ }^{\mathrm{b}} \mathrm{ChAT}$ activity, $\mathrm{HC} 3$ binding.

' $\beta A R, \alpha_{2} A R, m_{2} A C h R$ binding.

Basal, isoproterenol, $\mathrm{Mn}^{2+}$, forskolin, forskolin and clonidine, forskolin and carbachol. 

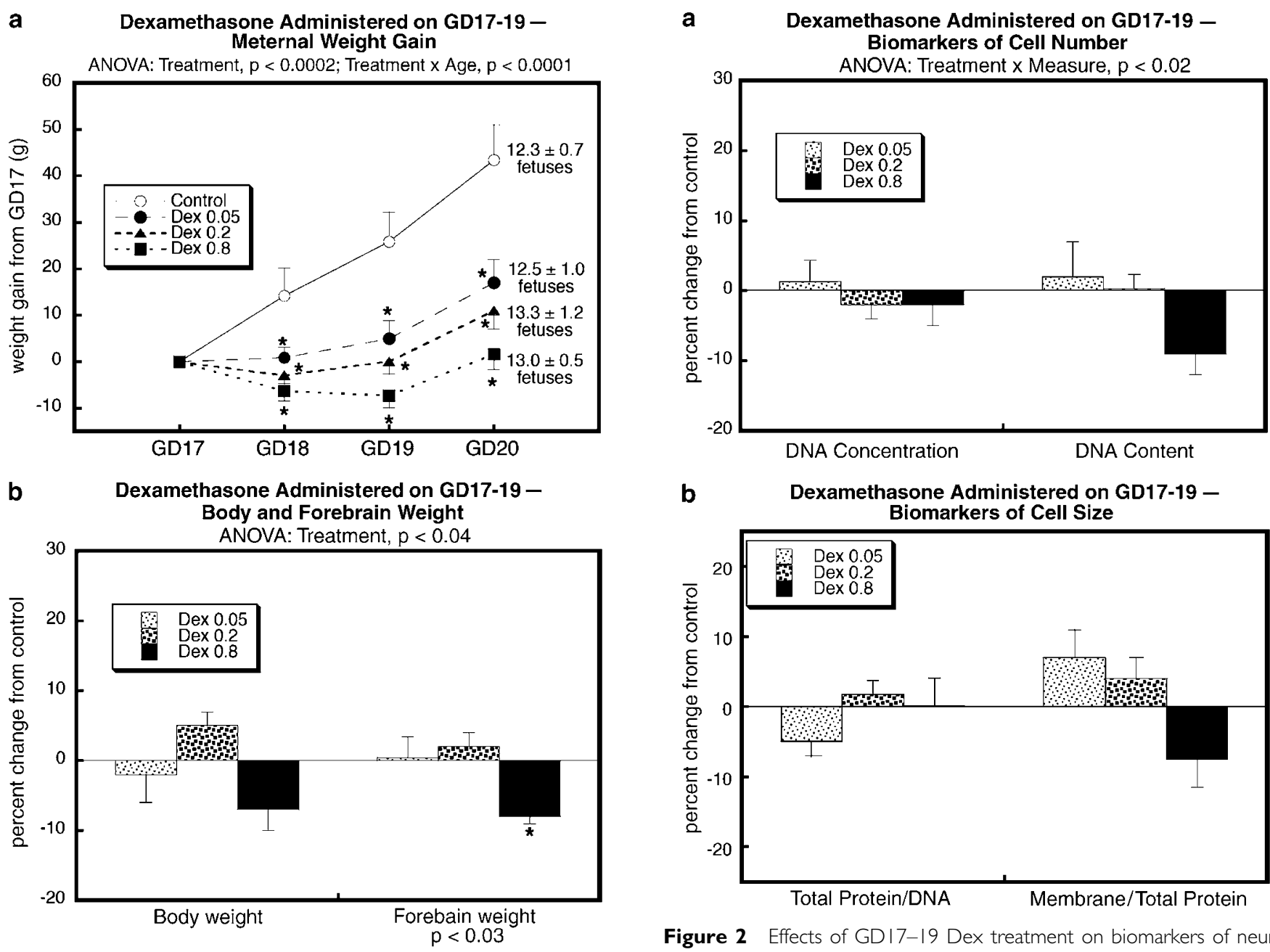

Figure I Effects of GDI7-19 Dex treatment on maternal weight gain and litter characteristics (a) and on body and forebrain weights in the fetuses on GD20 (b). For maternal weight gain, ANOVA across all doses and time points appears at the top of the panel; for fetal weights, ANOVA across all doses and both measures appears at the top and ANOVA for each measure appears at the bottom. Asterisks denote individual values that differ significantly from the corresponding control. There were no significant differences in maternal weights prior to the first Dex injection on GDI7 (313 $\pm 6 \mathrm{~g}$ across all groups).

Although there was little effect on biomarkers of presynaptic cholinergic development (Figure 3a), prenatal Dex administration elicited alterations in neurotransmitter receptor binding that differed among the various receptors $(p<0.07$ for the interaction of treatment $\times$ receptor type), with $\alpha_{2}$ ARs showing the largest effect, achieving statistically significant deficits at $0.8 \mathrm{mg} / \mathrm{kg}$ Dex (Figure $3 \mathrm{~b}$ ). Although the intermediate dose of Dex $(0.2 \mathrm{mg} / \mathrm{kg})$ produced a consistent increment in all measures of AC activity (Figure 3c), the effect did not achieve statistical significance.

\section{Dex Treatment on PN1-3}

In contrast to the relatively small effects of prenatal Dex administration on body and forebrain weights, treatment in the early postnatal period evoked marked growth retardation that was statistically significant at every dose (Figure 4). Brain sparing was evident by the smaller reduction in

Figure 2 Effects of GDI7-19 Dex treatment on biomarkers of neural cell development, evaluated on GD20: (a) DNA concentration and content and (b) protein/DNA ratio and membrane/total protein ratio. ANOVA across all doses and measures appears at the top of each panel. In addition, across all four measures, $0.8 \mathrm{mg} / \mathrm{kg}$ of Dex elicited a significant reduction $(p<0.02)$ but values for each individual measure did not achieve significance.

forebrain weight as compared to body weight $(p<0.02)$, and again, the same pattern was seen for whole brain weight (data not shown). The effects of PN1-3 Dex treatment on indices of cell number were also robust (Figure 5a). DNA concentration showed a $15 \%$ increase at the highest dose of Dex, connoting an increase in cell packing density. When superimposed on the impairment of forebrain growth, the change in DNA content, signifying the total number of cells in the forebrain, showed significant deficits at all Dex doses. Across both indices of cell size (total protein/DNA ratio, membrane protein/total protein ratio), there was a significant reduction caused by the highest Dex dose $(p<0.0001)$ but significance was not achieved with either ratio alone.

Dex administration on PN1-3 had significant effects on all aspects of synaptic development and cell signaling. For cholinergic presynaptic biomarkers, there was a small elevation of ChAT activity across all doses, at the margin of statistical significance (Figure 6a); in fact, across all three treatment regimens (GD17-19, PN1-3, PN7-9), there was a significant promotional effect on ChAT $(p<0.002)$ that 

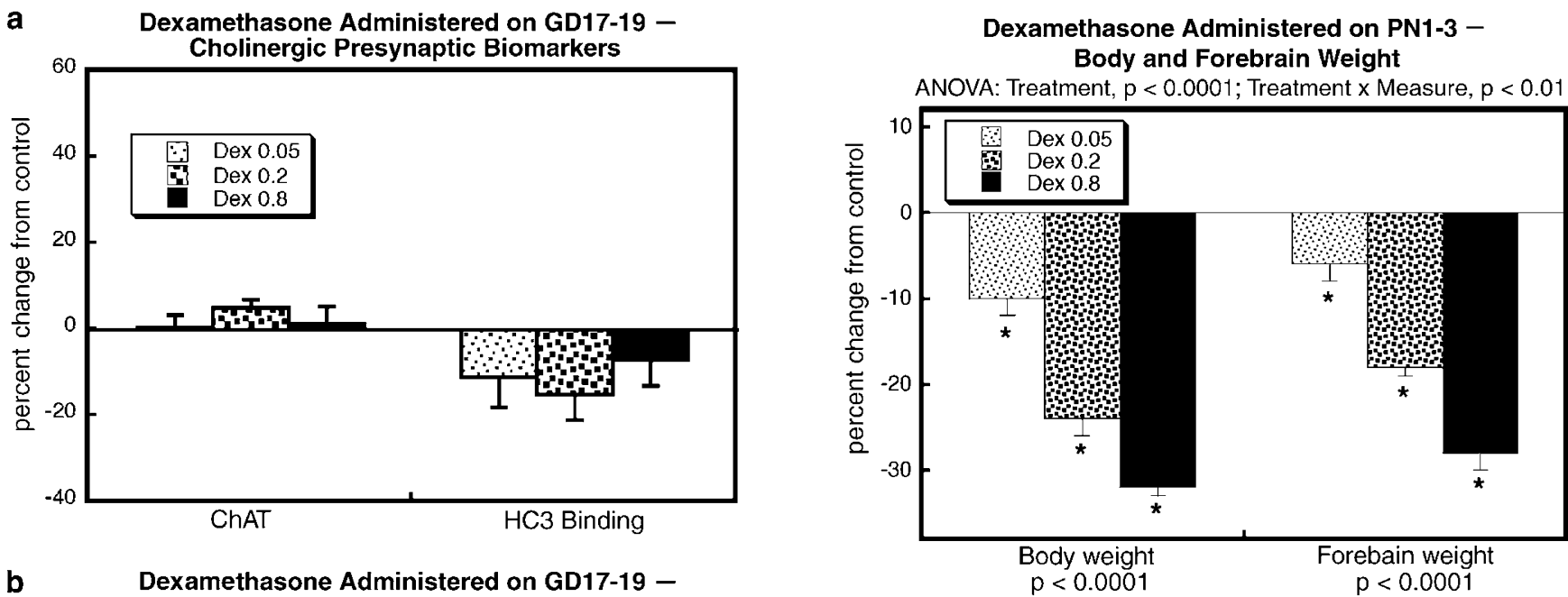

b Dexamethasone Administered on GD17-19 ANOVA: Treatment $x$ Measure, $\mathrm{p}<0.07$

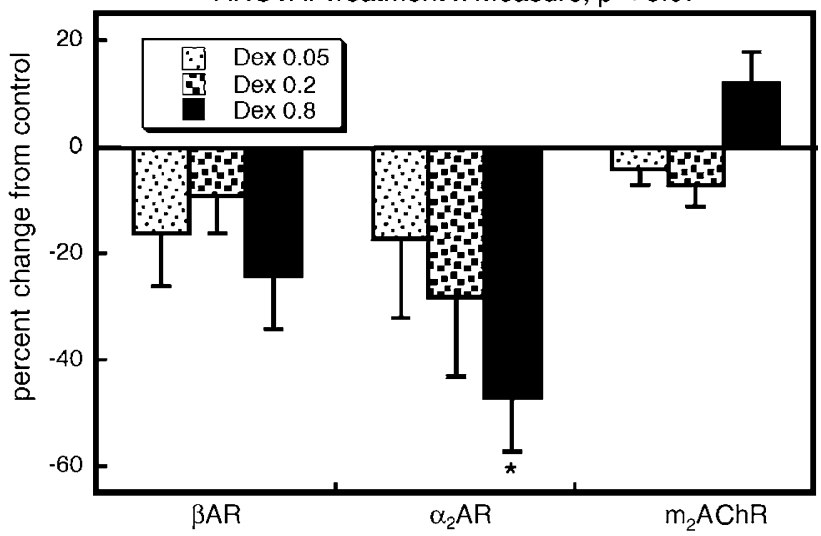

Figure 4 Effects of $\mathrm{PNI}-3$ Dex treatment on body and forebrain weights on PN4. ANOVA across all doses appears at the top of the panel and ANOVA for each measure appears at the bottom; asterisks denote individual values that differ significantly from the corresponding control. Data for males and females were combined for presentation because of the absence of a treatment $\times$ sex interaction.

single regimen would need to be interpreted with caution. Unlike the small effects on ChAT, HC3 binding showed a massive increase at the lowest of Dex (Figure 6a). Accompanying the increased impairment of growth and cell acquisition at higher Dex doses, the promotional effect on HC3 binding disappeared. As with prenatal Dex treatment, administration on PN1-3 reduced $\alpha_{2}$ AR binding but the effect was sex-selective, expressed only in males (Figure $6 \mathrm{~b}$ ).

The effects on AC signaling were far more profound

C Dexamethasone Administered on GD17-19 -

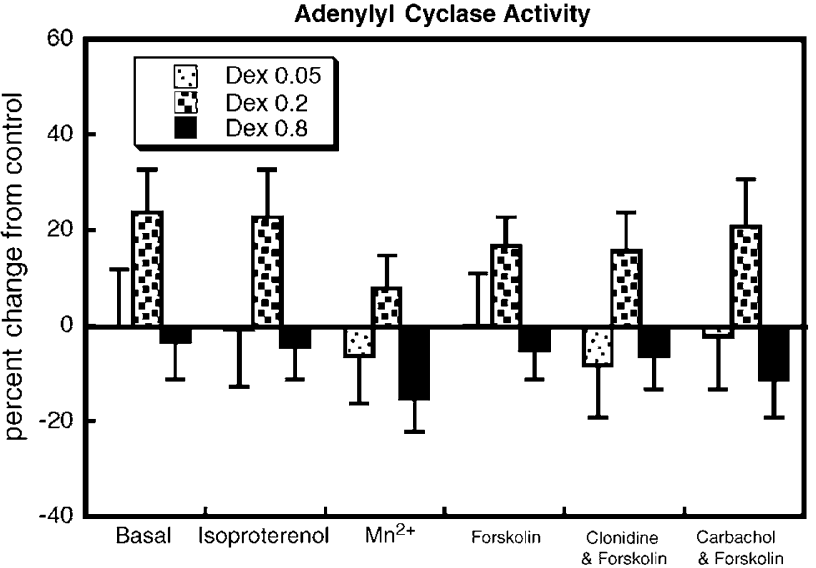

(Figure 6c). Dex treatment produced a dose-dependent increase across all AC measures, achieving $30-40 \%$ increases for the direct AC stimulants, $\mathrm{Mn}^{2+}$ and forskolin. Basal AC activity and the AC response to isoproterenol also showed increments of smaller magnitude. Owing to the significant interaction of treatment $\times$ measure $(p<0.03)$, we also assessed the relative effects of the different neurotransmitter receptor stimulants in relationship to the response to direct AC stimulants. Dex elicited a significant loss of the isoproterenol response relative to the maximum AC activity achieved with $\mathrm{Mn}^{2+}(p<0.009)$ or forskolin $(p<0.01)$. The ratio of isoproterenol/ $\mathrm{Mn}^{2+} \mathrm{AC}$ activity decreased from a control value of $0.128 \pm 0.006$ to $0.116 \pm 0.005$ in the $0.2 \mathrm{mg} / \mathrm{kg}$ Dex group, and to $0.111 \pm 0.004$ in the $0.8 \mathrm{mg} / \mathrm{kg}$ Dex group. Similarly, the isoproterenol/forskolin activity ratio dropped from $0.257 \pm 0.008$ to $0.237 \pm 0.007$ and $0.217 \pm 0.008$, respectively. Dex treatment also altered the AC response to $\mathrm{m}_{2} \mathrm{AChR}$ stimulation. In control forebrain, addition of carbachol reduced forskolin-stimulated activity by about $10 \%$ (ratio of activity with/without carbachol, $0.89 \pm 0.03$ ). This inhibitory response was lost in the Dex groups $(p<0.02)$, which showed no net effect of carbachol at $0.05 \mathrm{mg} / \mathrm{kg}$ (ratio of $0.96 \pm 0.03)$ or $0.2 \mathrm{mg} / \mathrm{kg}(1.00 \pm 0.02)$ with restoration of the response at the highest Dex dose (ratio of $0.88 \pm 0.04$ ).

In light of the profound effects of PN1-3 Dex adminisachieved statistical significance at all doses but without a significant treatment $\times$ regimen interaction. Accordingly, it is correct to conclude that there is an increase in ChAT but the presence or absence of statistical significance for any tration, we performed an additional study in which animals received one additional day of treatment (PN1-4, with evaluation on PN5). The more prolonged regimen elicited 
a Dexamethasone Administered on PN1-3 Biomarkers of Cell Number ANOVA: Treatment, $p<0.02$; Treatment $x$ Measure, $p<0.0001$

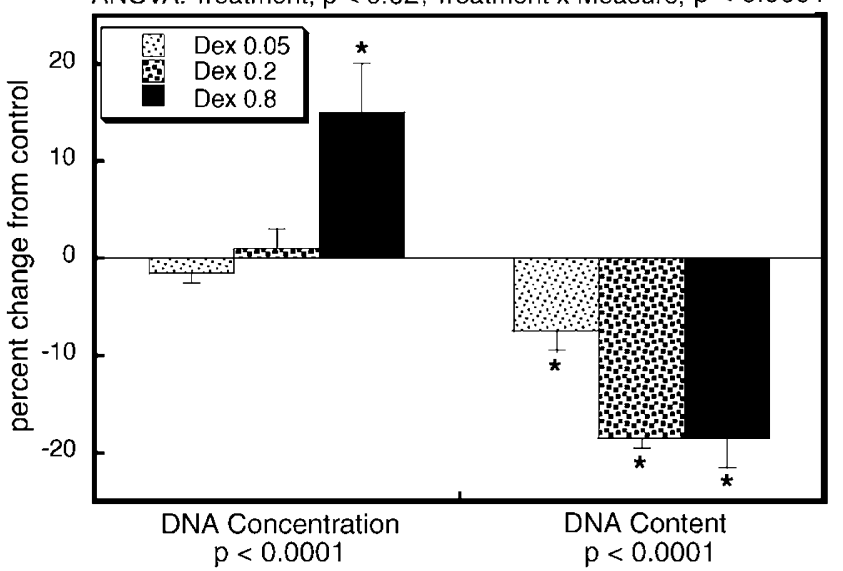

b Dexamethasone Administered on PN1-3 Biomarkers of Cell Size
ANOVA: Treatment, $p<0.004$

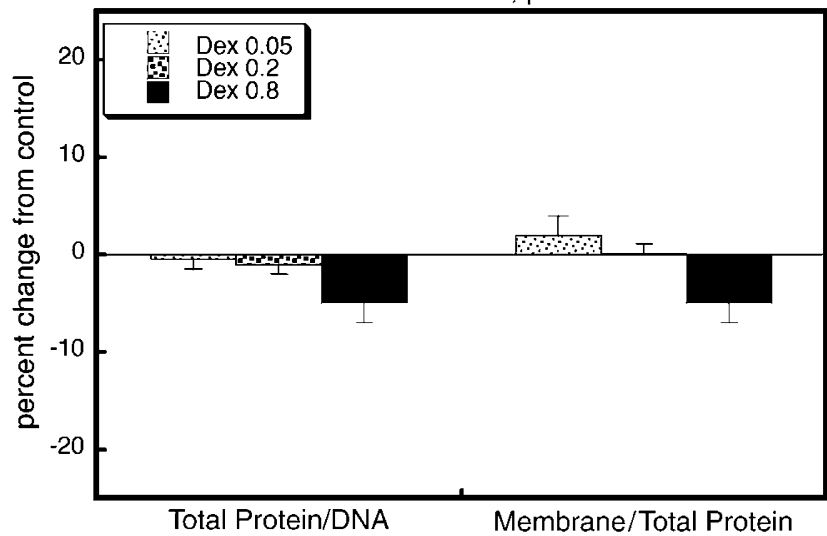

Figure 5 Effects of PNI-3 Dex treatment on biomarkers of neural cell development, evaluated on PN4: (a) DNA concentration and content and (b) protein/DNA ratio and membrane/total protein ratio. ANOVA across all doses and both measures appears at the top of each panel and ANOVA for each measure appears at the bottom; asterisks denote individual values that differ significantly from the corresponding control. The main effect in (b) reflects a significant deficit evoked by Dex $0.8 \mathrm{mg} / \mathrm{kg}(p<0.000 \mathrm{I})$ but neither ratio alone achieved statistical significance. Data for males and females were combined for presentation because of the absence of a treatment $\times$ sex interaction.

much larger deficits in body weight than were seen with PN1-3 treatment: a $20 \%$ deficit in the $0.05 \mathrm{mg} / \mathrm{kg}$ Dex group, $35 \%$ in the $0.2 \mathrm{mg} / \mathrm{kg}$ Dex group, and $45 \%$ in the $0.8 \mathrm{mg} / \mathrm{kg}$ Dex group (Table 3). The effects on forebrain growth were also correspondingly greater than seen with the three-dose regimen but brain sparing was evident from the smaller effect on the forebrain as compared to body weight. Brain weight deficits for the three treatments were 10,25 , and $35 \%$, respectively. More importantly, the extended Dex treatment compromised subsequent viability, with significant mortality in the preweaning period, an effect not seen with the PN1-3 regimen (data not shown).

\section{Dex Treatment on PN7-9}

With a shift in the regimen toward later postnatal treatment, Dex elicited a smaller degree of growth impairment than a

Dexamethasone Administered on PN1-3 Cholinergic Presynaptic Biomarkers

ANOVA: Treatment, $P<0.04$; Treatment $x$ Measure, $P<0.04$

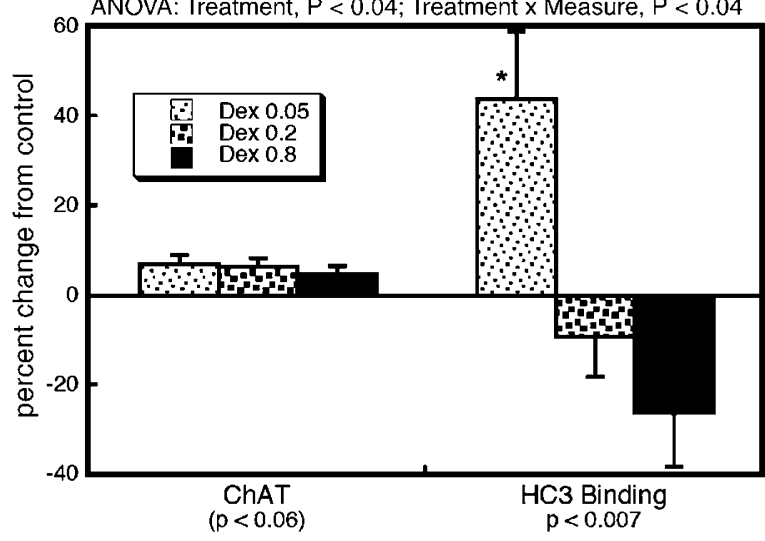

b Dexamethasone Administered on PN1-3 Neurotrnsmitter Receptor Binding ANOVA: Treatment $x$ Sex, $p<0.01$; Treatment $x$ Sex $x$ Reporter Type, $p<0.002$ $\alpha_{2}$ AR: Treatment $x$ Sex, $p<0.008$

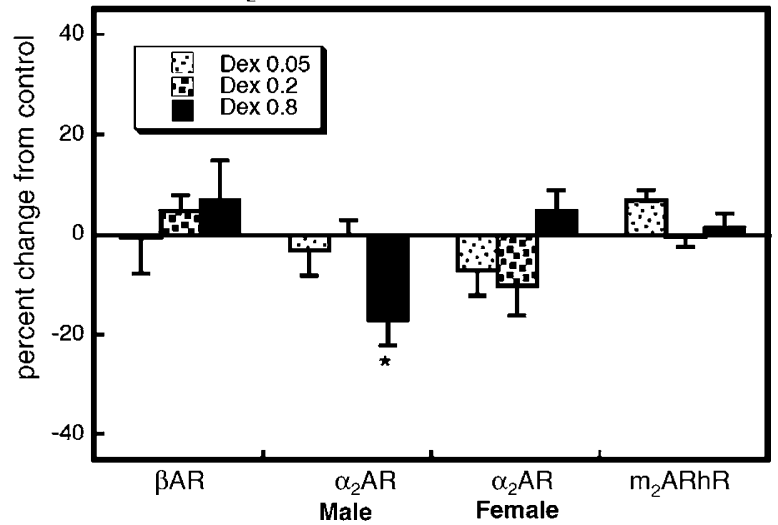

C Dexamethasone Administered on PN1-3 Adenylyl Cyclase Activity

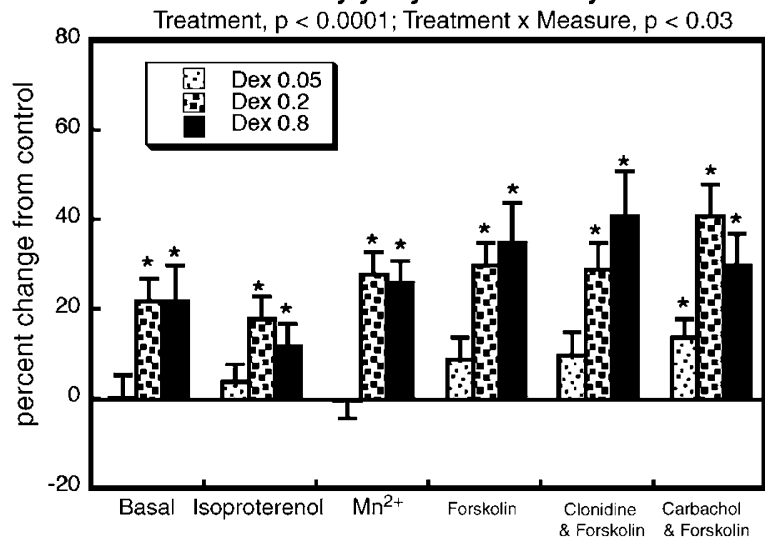

Figure 6 Effects of $\mathrm{PNI}-3$ Dex treatment on biomarkers of synaptic development and responsiveness, evaluated on PN4: (a) presynaptic cholinergic indices, ChAT activity, and $\mathrm{HC} 3$ binding; (b) neurotransmitter receptor binding for $\beta A R s, \alpha_{2} A R s$, and $m_{2} A C h R s$; and (c) indices of $A C$ signaling. ANOVA across all doses and both measures appears at the top of each panel and ANOVA for each measure appears at the bottom; asterisks denote individual values that differ significantly from the corresponding control. For all determinations except $\alpha_{2} A R$ binding, data for males and females were combined for presentation because of the absence of a treatment $\times$ sex interaction 
Table 3 Dexamethasone Administration on PNI-4 (Four Injections)

\begin{tabular}{llccc}
\hline & Control & $\begin{array}{c}\text { Dex 0.05 } \\
\mathbf{m g} / \mathbf{k g}\end{array}$ & $\begin{array}{c}\text { Dex 0.2 } \\
\mathbf{m g} / \mathbf{k g}\end{array}$ & $\begin{array}{c}\text { Dex 0.8 } \\
\mathbf{m g} / \mathbf{k g}\end{array}$ \\
\hline Body weight (g) & $12.6 \pm 0.2$ & $10.2 \pm 0.2$ & $8.0 \pm 0.2$ & $6.7 \pm 0.1$ \\
Forebrain weight (mg) & $294 \pm 4$ & $262 \pm 5$ & $223 \pm 5$ & $185 \pm 4$ \\
\hline
\end{tabular}

Each treatment group consisted of 18 males and 18 females and evaluations were conducted $24 \mathrm{~h}$ after the last dose. ANOVA indicates significant deficits in body weight $(p<0.000 \mathrm{I})$ and forebrain weight $(p<0.000 \mathrm{I})$ and the effects were also significant for each individual Dex group compared to control.

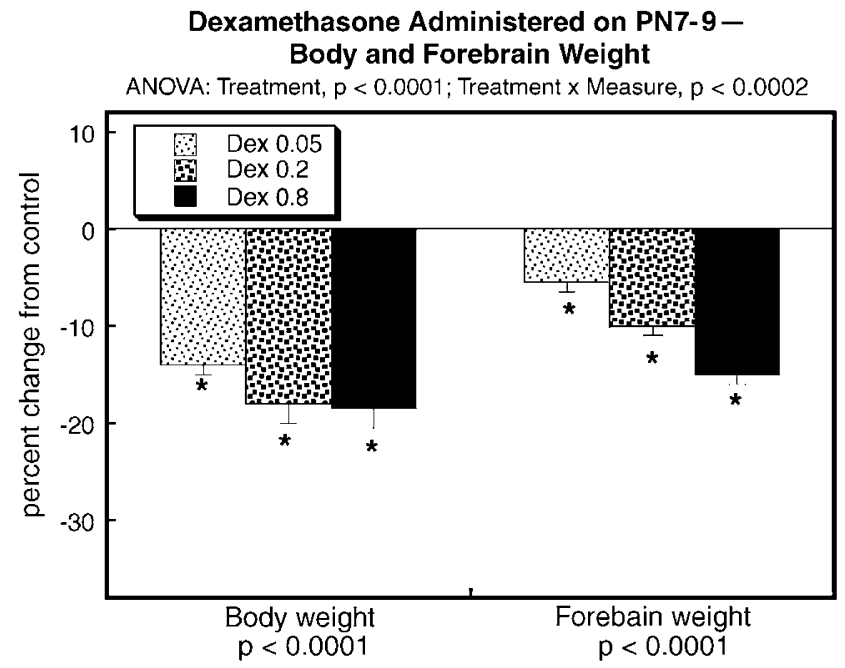

Figure 7 Effects of PN7-9 Dex treatment on body and forebrain weights on PNI 0. ANOVA across all doses and both measures appears at the top of the panel and ANOVA for each measure appears at the bottom; asterisks denote individual values that differ significantly from the corresponding control. Data for males and females were combined for presentation because of the absence of a treatment $\times$ sex interaction.

was seen on PN1-3. Although body and forebrain weights (and whole brain weights, not shown) were significantly reduced at all three doses of Dex, the maximum effect was only about half to two-thirds of that seen earlier (Figure 7). Again, brain sparing was evident from the significantly $(p<0.0001)$ smaller effects on forebrain weight as compared to body weight. The adverse effects of Dex on biomarkers of neural cell development were also correspondingly reduced in the animals receiving treatment on PN7-9. There were no significant effects on the DNA concentration, and the deficits in DNA content ranged from 5 to $15 \%$ (Figure 8a). Nevertheless, the reduction in membrane/total protein ratio was just as large as had been seen with early postnatal Dex treatment (Figure $8 \mathrm{~b}$ ).

As before, there was a small, but statistically significant increase in ChAT activity in the Dex-treated animals but in this case there was no promotional effect on HC3 binding (Figure 9a). However, actions directed toward neurotransmitter receptors were far more prominent (Figure 9b). All three receptor types showed significant increases in the Dex groups but with clearcut sex selectivity and a distinctly nonmonotonic response. Receptor binding was augmented a

Dexamethasone Administered on PN7-9Biomarkers of Cell Number ANOVA: Treatment, $p<0.02$; Treatment $x$ Measure, $p<0.0001$

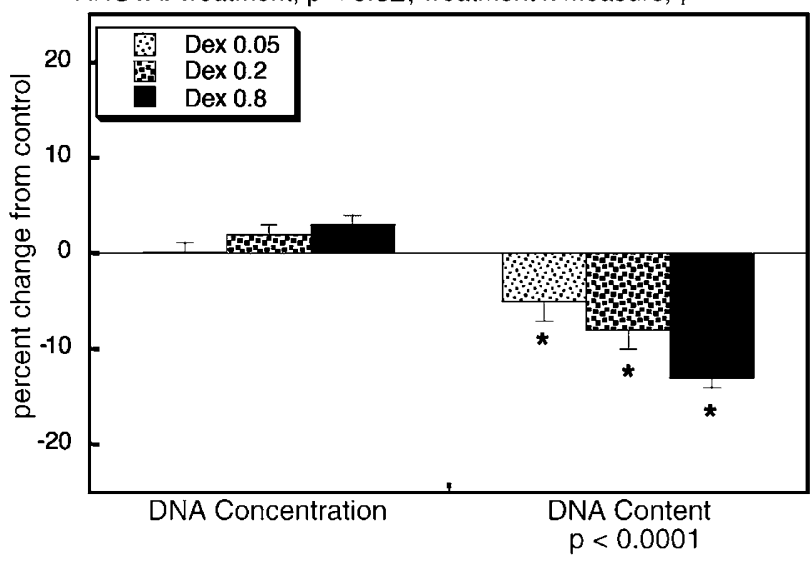

b Dexamethasone Administered on PN7-9 Biomarkers of Cell Size

ANOVA: Treatment, $p<0.03$; Treatment $x$ Measure, $p<0.02$

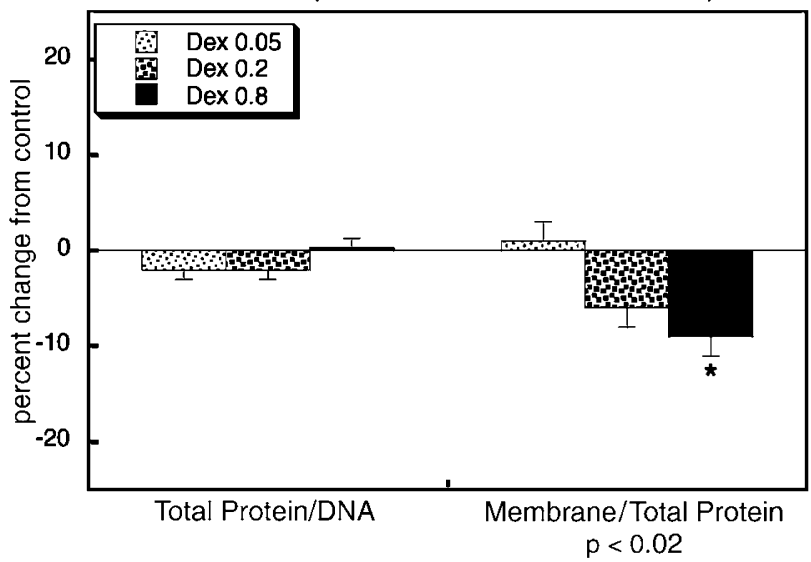

Figure 8 Effects of PN7-9 Dex treatment on biomarkers of neural cell development, evaluated on PNI O: (a) DNA concentration and content and (b) protein/DNA ratio and membrane/total protein ratio. ANOVA across all doses and both measures appears at the top of each panel and ANOVA for each measure appears at the bottom; asterisks denote individual values that differ significantly from the corresponding control. Data for males and females were combined for presentation because of the absence of a treatment $\times$ sex interaction.

by Dex far more in males than in females $(p<0.005)$ and in addition, the effect peaked at $0.2 \mathrm{mg} / \mathrm{kg}$ and then declined at the highest Dex dose $(p<0.02$ comparing $0.2-0.8 \mathrm{mg} / \mathrm{kg}$ across all three receptors). Superimposed on this general pattern, the magnitude of the increase was much larger for the adrenergic receptors (40\% maximum increase) than for $\mathrm{m}_{2} \mathrm{AChRs}$ (10\% increase). The effects of PN7-9 Dex treatment on AC signaling were similarly much larger than had been seen with PN1-3 treatment, achieving increases of as much as $60 \%$ at the highest dose (Figure $9 \mathrm{c}$ ). As before, the biggest changes were seen for responses to direct AC stimulants $\left(\mathrm{Mn}^{2+}\right.$, forskolin with or without other additions) as compared to basal AC activity or the response to isoproterenol. In light of the interaction of Dex treatment $\times$ AC measure $(p<0.02)$, we again compared responses to neurotransmitter stimulants relative to total $\mathrm{AC}$ activity assessed with $\mathrm{Mn}^{2+}$ or forskolin. In males, Dex at all doses reduced the response to isoproterenol relative to 
a

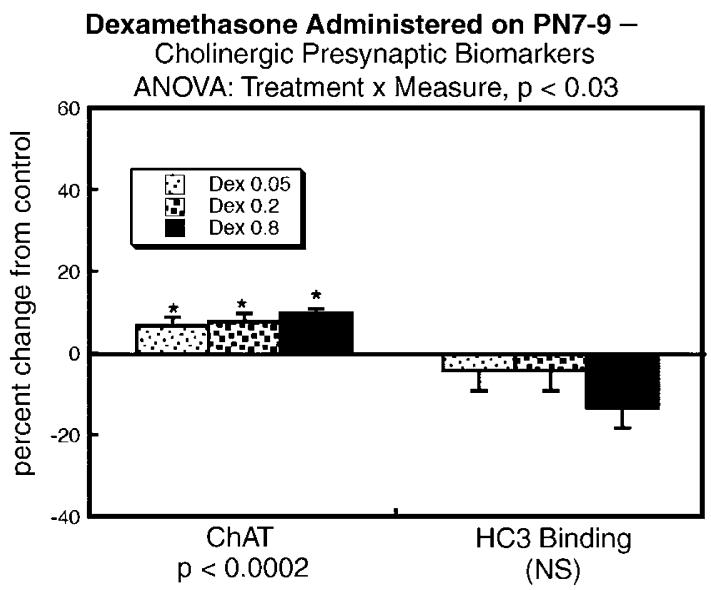

b Dexamethasone Administered on PN7-9 Neurotransmitter Receptor Binding

ANOVA: Treatment, $\mathrm{p}<0.03$; Treatment $x$ Sex, $\mathrm{p}<0.005$ Treatment $x$ Sex $x$ Receptor Type, $p<0.02$

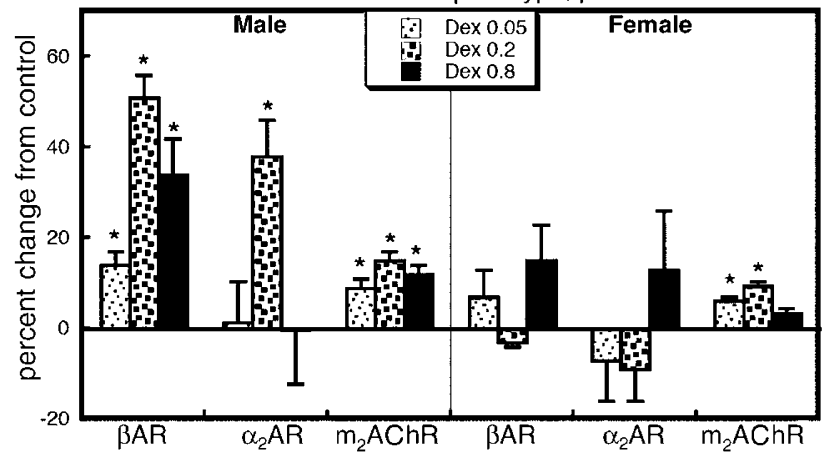

C Dexamethasone Administered on PN7-9 Adenylyl Cyclase Activity Treatment, $p<0.002$; Treatment $x$ Measure, $p<0.02$

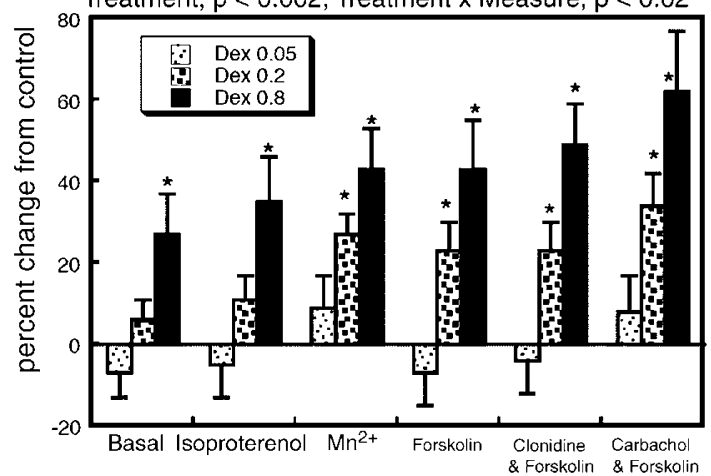

Figure 9 Effects of PN7-9 Dex treatment on biomarkers of synaptic development and responsiveness, evaluated on PNIO: (a) presynaptic cholinergic indices, ChAT activity, and $\mathrm{HC} 3$ binding; (b) neurotransmitter receptor binding for $\beta A R s, \alpha_{2} A R s$, and $m_{2} A C h R s ;$ and (c) indices of $A C$ signaling. ANOVA across all doses and both measures appears at the top of each panel and ANOVA for each measure appears at the bottom; asterisks denote individual values that differ significantly from the corresponding control. For (a) and (c), data for males and females were combined for presentation because of the absence of a treatment $x$ sex interaction

$\mathrm{Mn}^{2+}$-stimulated AC $(p<0.02): 0.103 \pm 0.006$ in controls, $0.082 \pm 0.007$ in the $0.05 \mathrm{mg} / \mathrm{kg}$ Dex group, $0.076 \pm 0.003$ in the $0.2 \mathrm{mg} / \mathrm{kg}$ Dex group, $0.084 \pm 0.005$ in the $0.8 \mathrm{mg} / \mathrm{kg}$ Dex group. Effects on the isoproterenol/forskolin ratio were also statistically significant $(p<0.04)$ and the corresponding values were $0.29 \pm 0.03,0.22 \pm 0.02,0.22 \pm 0.01$ and $0.22 \pm$ 0.01 , respectively.

\section{DISCUSSION}

Our results indicate that Dex, at doses commensurate with its use in preterm labor, and also at doses well below therapeutic levels, alters neural cell development through multiple mechanisms that can contribute a broad spectrum of potential, long-term effects. Superimposed on this general vulnerability, we found evidence for a critical window of heightened sensitivity to adverse effects of Dex on the developing brain, centered around the first 10 days postpartum in the rat, corresponding to the period in human fetal neurodevelopment in which glucocorticoids are likely to be used (Dobbing and Sands, 1979; Gilstrap et al, 1994; Rodier, 1988).

Of the three different regimens, Dex administration on GD17-19 elicited the smallest degree of somatic growth retardation, deficits of forebrain weight, or alterations of neurochemical markers, despite the fact that the treatment produced clearcut reductions of maternal weight gain. To some extent, the lowered sensitivity in gestation may represent pharmacokinetic differences engendered by maternal catabolism of Dex, thus reducing the effective dose delivered to the fetus. Indeed, although Dex readily crosses the rat placenta, fetal levels are considerably lower than those in the dam (Seckl, 2004; Varma, 1986). Nevertheless, superimposed on this basic difference, the comparative dose-effect relationships across the different treatment windows can be used to evaluate the relative sensitivity of the brain itself to the effects of Dex. Treatment with $0.8 \mathrm{mg} / \mathrm{kg}$ on GD17-19 produced the same degree of somatic and forebrain growth inhibition as was seen at lower doses on PN1-3 or PN7-9, yet was devoid of the robust changes seen in neural cell acquisition, cholinergic biomarkers, receptor binding, and cell signaling parameters, all of which were prominent after postnatal Dex administration. However, we did obtain evidence for some alterations with gestational treatment, including a small degree of neural cell loss and prominent suppression of $\alpha_{2}$ ARs, a receptor type that is overexpressed and linked to cell replication during neurodevelopment (Duncan et al, 1990; Kreider et al, 2004; Lidow et al, 1991; Slotkin et al, 1994b). Furthermore, because we examined the entire forebrain, this leaves open the likelihood of missing more focal effects of Dex that may be diluted by the inclusion of large amounts of unaffected subregions. Indeed, we have already identified persistent changes in hippocampal cholinergic indices and related behavioral performance after GD17-19 treatment with $0.2 \mathrm{mg} / \mathrm{kg}$ of Dex, a dose that did not elicit detectable changes at the $24 \mathrm{~h}$ time point in any of the parameters evaluated here (Kreider et al, 2005). Accordingly, although the present findings indicate a lesser sensitivity to Dex as compared to later developmental stages, these results should not be interpreted as total sparing from the adverse effects of Dex during this period.

With a shift in the treatment window to PN1-3, Dex elicited a much greater degree of somatic and brain growth inhibition. By itself, even transient growth retardation enhances the subsequent incidence of a broad range of 
cardiovascular and metabolic disorders (Barker, 2003; Khan et al, 2003; Lackland et al, 2003; Phillips, 2002). Similarly, Dex treatment of preterm infants increases the likelihood of hypertension and hyperglycemia (Le Cras et al, 2000; Nyirenda et al, 2001; Ortiz et al, 2003), which is in accord with our findings for growth retardation in the rat model. All the same, the most striking effects seen here were on biomarkers of neural cell acquisition, synaptogenesis, and synaptic signaling, displaying significant effects of Dex even at 0.05 or $0.2 \mathrm{mg} / \mathrm{kg}$, doses below or at the lower end of those used clinically. Superimposed on this basic finding, there was a distinct shift in cellular target when Dex was given on PN1-3 as compared to PN7-9. With the early neonatal treatment, there was greater impairment of forebrain growth and cell acquisition, whereas receptors and cell signaling showed the greatest sensitivity with the later treatment. To a large extent, this dichotomy is a logical consequence of the specific events surrounding the two different periods: the early neonatal period involves a more rapid brain growth spurt with the attendant need for generation of new cells, whereas the later phase involves neural cell differentiation and synaptogenesis, with the attendant development of synaptic signaling (Dobbing and Sands, 1979; Rodier, 1988). Taken together, these differences reinforce the idea that Dex affects brain development through multiple mechanisms, each of which has a distinct peak of developmental sensitivity.

Accordingly, the long-term outcomes of Dex are likely to be quite different depending upon the critical window in which exposure occurs. Indeed, our results for the biomarkers of cell number and size also indicate fundamental differences in the outcomes of the different Dex regimens. Although there were only minor effects after treatment on GD17-19, the group given Dex on PN1-3 showed a decrease in DNA content, signifying deficits in the total of number of neural cells. At the highest dose, the cell packing density (DNA per gram tissue) was increased whereas indices of cell size indicated a relative decline. This pattern allows for inferences to be drawn about the specific cellular targets. Since glia are smaller than neurons, neuronal loss accompanied by partial glial replacement will produce precisely this archetype, representing reactive gliosis that is a characteristic of neuronal injury (O'Callaghan, 1993). With the shift to treatment on PN7-9, the decrease in total cell number was not accompanied by a drop in the total protein/DNA ratio but only by a decrease in the membrane/total protein ratio, suggestive of impaired development of neuritic projections, as might be expected from targeting of later events in neurodevelopment. Obviously, these conclusions from biochemical findings need to be confirmed by morphological investigations but our findings point the way to the specific types of alterations that are likely to be found.

The effects of Dex on indices of synaptic development, neurotransmitter receptor expression, and cell signaling are particularly important in light of the trophic roles of acetylcholine and norepinephrine in forebrain development (Dreyfus, 1998; Hohmann, 2003; Hohmann and BergerSweeney, 1998; Lauder and Schambra, 1999; WhitakerAzmitia, 1991). Dex administration on PN1-3 enhanced ChAT activity and HC3 binding, suggesting an accelerated differentiation of cholinergic nerve terminals. Shifting the treatment window to PN7-9 still produced the increase in ChAT but the effect on HC3 binding was lost, suggesting a lessened effect of Dex on this particular developmental event. Indeed, the augmentation of cholinergic development appears to occupy a very restricted time-frame and dose requirement, as even with the $\mathrm{PN} 1-3$ treatment, raising the dose of Dex into the therapeutic range $(0.2$ or $0.8 \mathrm{mg} / \mathrm{kg})$ reversed the promotional effect. This biphasic response has been noted before (Slotkin et al, 1991a; Zahalka et al, 1993b) and the interpretation is relatively straightforward: enhanced differentiation evoked by Dex is offset when the dose is raised sufficiently to impair general development consequent to growth inhibition. Indeed, in the current work, we observed similar biphasic responses for effects of PN7-9 Dex administration on adrenergic receptors, indicating that this is a more general phenomenon.

Interestingly, the largest effects on receptors involved those that are overexpressed during brain development ( $\left.\beta \mathrm{AR}, \alpha_{2} \mathrm{AR}\right)$, rather than the $\mathrm{m}_{2} \mathrm{AChRs}$, which are not. These findings suggest a specific link between Dex administration and effects mediated by neurotransmitter receptors with specific trophic roles in the developing brain. Indeed, the sharp dichotomy in the effects of $\alpha_{2} \mathrm{AR}$ stimulation on AC activity point out the different roles of the overexpressed receptors during specific phases of development: clonidine was inhibitory on PN4 but stimulatory on PN10. Nevertheless, it is the enhancement of $\beta \mathrm{AR}$ expression by Dex that may be of particular relevance. Terbutaline, a $\beta \mathrm{AR}$ agonist, is frequently administered to arrest preterm labor (Lam et al, 1998), and this drug also penetrates to the fetus to stimulate $\beta$ ARs in the developing brain, impairing cell acquisition and producing lasting synaptic and structural anomalies (Meyer et al, 2005; Rhodes et al, 2004a,b; Slotkin et al, 2003). Dex and terbutaline are almost always given together in the therapy of preterm labor, and our findings suggest the strong likelihood of additive or synergistic effects on neurodevelopment, a possibility highlighted for future study (Gilstrap et $a l, 1994)$. Of further interest, the effects of Dex on adrenergic receptor expression and on $\beta \mathrm{AR}$-mediated AC stimulation were among the only ones in which we found a sharp distinction between males and females. Dex influences testosterone synthesis and metabolism (Reznikov et al, 2004) and in turn, testosterone regulates the expression of $\alpha_{2}$ ARs (Dygalo et al, 2002). Although parallel studies have not been conducted for sex-dependent effects on $\beta \mathrm{AR}$ expression, there are steroid-binding sites in the $\beta$ AR promoter (Cornett et al, 1998), so that such differences may also exist for this receptor. In either case, the sexselective effects of Dex on adrenergic receptors and corresponding cell signaling during this critical period are likely to contribute to long-term effects. Both $\alpha_{2}$ ARs and $\beta$ ARs exert direct control over neural cell replication and apoptotic cell elimination as required for architectural assembly of the brain (Duncan et al, 1990; Garofolo et al, 2003; Kreider et al, 2004; Lidow and Rakic, 1995; Popovik and Haynes, 2000; Slotkin et al, 1988; Zhu et al, 1998). Glucocorticoid effects on adrenergic receptor expression and signaling may thus provide a contributory mechanism to the sex-selectivity seen for the ultimate behavioral outcomes (Bowman et al, 2004; Kreider et al, 2005). 
In keeping with an earlier report (Slotkin et al, 1994a), gestational Dex treatment had only minor effects on AC signaling, but in contrast, we found that postnatal treatments evoked massive increases in all aspects of signal transduction through this pathway. Since the largest effects were seen for the response to direct AC stimulants $\left(\mathrm{Mn}^{2+}\right.$, forskolin), it is most likely that Dex induces the expression of $\mathrm{AC}$, leading to substantial increases in the number of membrane-associated AC molecules; we did not find significant changes in the relative response to forskolin $v s$ $\mathrm{Mn}^{2+}$, suggesting that Dex does not alter the AC isoform being expressed, but rather simply increases the total number of AC molecules. Accordingly, Dex administration produces 'heterologous' sensitization of the pathway, increasing the ability of all inputs to evoke an increase in cyclic AMP formation, as demonstrated here for basal AC activity and disparate neurotransmitter receptor stimulants. Given the pivotal role played by cyclic AMP in the switch from cell replication to differentiation, and the fact that prolonged overproduction elicits apoptosis (Claycomb, 1976; Gu et al, 2000; Hultgårdh-Nilsson et al, 1994; Slotkin et al, 2003), the global induction of AC is thus likely to play a direct role in the adverse effects of Dex on cell acquisition, and also to sensitize developing neural cells to other stimuli that may then contribute to additional or later-emerging effects. We also found evidence for impaired G-protein signaling, as evidenced by changes in the response to carbachol (loss of $\mathrm{m}_{2} \mathrm{AChR}$-mediated inhibitory actions) and isoproterenol (reduced proportion of total AC activity responding to $\beta \mathrm{AR}$ stimulation), so that Dex may also compromise specific receptor-mediated responses, superimposed on the general increases in AC. Notably, too, Dexinduced changes in receptor-mediated AC signaling were generally unrelated to effects on receptor expression, in keeping with earlier observations that G-protein coupling per se is a more important determinant of the net response to receptor stimulation (Slotkin et al, 2003; Vatner et al, 1998).

In conclusion, Dex administration during a critical developmental window evokes a wide range of cellular defects in the developing forebrain, comprising actions directed toward cell acquisition, synaptic development, neurotransmitter receptor expression, and cell signaling. Importantly, these effects are all exerted with Dex doses at or below those used clinically in the management of preterm infants. Given the fact that hundreds of thousands of infants receive such treatment annually in the US, our findings suggest the need for a careful evaluation of the long-term neurodevelopmental liabilities engendered by glucocorticoid use.

\section{ACKNOWLEDGEMENTS}

This study was supported by NIH HD09713. We thank Charlotte A Tate for technical assistance.

\section{REFERENCES}

Auman JT, Seidler FJ, Slotkin TA (2000). Neonatal chlorpyrifos exposure targets multiple proteins governing the hepatic adenylyl cyclase signaling cascade: implications for neurotoxicity. Dev Brain Res 121: 19-27.
Auman JT, Seidler FJ, Slotkin TA (2001a). Regulation of fetal cardiac and hepatic $\beta$-adrenoceptors and adenylyl cyclase signaling: terbutaline effects. Am J Physiol 281: R1079-R1089.

Auman JT, Seidler FJ, Tate CA, Slotkin TA (2001b). Adrenoceptormediated cell signaling in the neonatal heart and liver: responses to terbutaline. Am J Physiol 281: R1895-R1901.

Barker DJP (2003). The developmental origins of adult disease. Eur J Epidemiol 18: 733-736.

Barrington KJ (2001). The adverse neuro-developmental effects of postnatal steroids in the preterm infant: a systematic review of RCTs. BMC Pediatr 1: 1-9.

Bell JM, Whitmore WL, Queen KL, Orband-Miller L, Slotkin TA (1987). Biochemical determinants of growth sparing during neonatal nutritional deprivation or enhancement: ornithine decarboxylase, polyamines, and macromolecules in brain regions and heart. Pediatr Res 22: 599-604.

Benesová O, Pavlík A (1989). Perinatal treatment with glucocorticoids and the risk of maldevelopment of the brain. Neuropharmacology 28: 89-97.

Bohn MC (1984). Glucocorticoid induced teratologies of the nervous system. In: Yanai J (ed). Neurobehavioral Teratology. Elsevier: Amsterdam. pp 365-387.

Bowman RE, MacLusky NJ, Sarmiento Y, Frankfurt M, Gordon M, Luine VN (2004). Sexually dimorphic effects of prenatal stress on cognition, hormonal responses, and central neurotransmitters. Endocrinology 145: 3778-3787.

Claycomb WC (1976). Biochemical aspects of cardiac muscle differentiation. J Biol Chem 251: 6082-6089.

Cornett LE, Hiller FC, Jacobi SE, Cao WH, McGraw DW (1998). Identification of a glucocorticoid response element in the rat $\beta_{2}$-adrenergic receptor gene. Mol Pharmacol 54: 1016-1023.

Crowther CA, Harding J (2003). Repeat doses of prenatal corticosteroids for women at risk of preterm birth for preventing neonatal respiratory disease. Cochrane Database Systemat Rev 1: CD003935.

Dammann O, Matthews SG (2001). Repeated antenatal glucocorticoid exposure and the developing brain. Pediatr Res 50: 563-564.

Davies AO, Lefkowitz RJ (1984). Regulation of $\beta$-adrenergic receptors by steroid hormones. Ann Rev Physiol 46: 119-130.

Dean F, Yu C, Lingas RI, Matthews SG (2001). Prenatal glucocorticoid modifies hypothalamo-pituitary-adrenal regulation in prepubertal guinea pigs. Neuroendocrinology 73: 194-202.

Dobbing J, Sands J (1979). Comparative aspects of the brain growth spurt. Early Hum Dev 3: 79-83.

Dreyfus CF (1998). Neurotransmitters and neurotrophins collaborate to influence brain development. Perspect Dev Neurobiol 5: 389-399.

Duncan CP, Seidler FJ, Lappi SE, Slotkin TA (1990). Dual control of DNA synthesis by $\alpha$ - and $\beta$-adrenergic mechanisms in normoxic and hypoxic neonatal rat brain. Dev Brain Res 55: 29-33.

Dygalo NN, Kalinina TS, Sournina NY, Shishkina GT (2002). Effects of testosterone on $\alpha_{2 \mathrm{~A}}$-adrenergic receptor expression in the rat brain. Psychoneuroendocrinology 27: 585-592.

Felszeghy K, Bagdy G, Nyakas C (2000). Blunted pituitaryadrenocortical stress response in adult rats following neonatal dexamethasone treatment. J Neuroendocrinol 12: 1014-1021.

Fuxe K, Cintra A, Chadi G, Gustafsson JA, Agnati LF (1994). Central glucocorticoid receptors and neuronal plasticity. Meth Neurosci 22: 372-382.

Fuxe K, Diaz R, Cintra A, Bhatnagar M, Tinner B, Gustafsson JA et al (1996). On the role of glucocorticoid receptors in brain plasticity. Cell Mol Neurobiol 16: 239-258.

Garofolo MC, Seidler FJ, Auman JT, Slotkin TA (2002). Adrenergic modulation of muscarinic cholinergic receptor expression and function in the developing heart. Am J Physiol 282: R1356-R1363. 
Garofolo MC, Seidler FJ, Cousins MM, Tate CA, Qiao D, Slotkin TA (2003). Developmental toxicity of terbutaline: critical periods for sex-selective effects on macromolecules and DNA synthesis in rat brain, heart, and liver. Brain Res Bull 59: 319-329.

Gilad GM, Gilad VH, Eliyayev Y, Rabey JM (1998). Developmental regulation of the brain polyamine-stress-response. Int $\mathrm{J} \mathrm{Dev}$ Neurosci 16: 271-278.

Gilstrap LC, Christensen R, Clewell WH, D'Alton ME, Davidson EC, Escobedo MB et al (1994). Effect of corticosteroids for fetal maturation on perinatal outcomes. J Am Med Assoc 273: 413-418.

Gould E, Tanapat P, McEwen BS (1997). Activation of the type 2 adrenal steroid receptor can rescue granule cells from death during development. Dev Brain Res 101: 265-268.

$\mathrm{Gu}$ CH, Ma YC, Benjamin J, Littman D, Chao MV, Huang XY (2000). Apoptotic signaling through the $\beta$-adrenergic receptor: a new $\mathrm{G}_{\mathrm{s}}$ effector pathway. J Biol Chem 275: 20726-20733.

Hodges-Savola C, Rogers SD, Ghilardi JR, Timm DR, Mantyh PW (1996). Adrenergic receptors regulate astrogliosis and cell proliferation in the central nervous system in vivo. Glia 17: $52-62$.

Hohmann CF (2003). A morphogenetic role for acetylcholine in mouse cerebral neocortex. Neurosci Biobehav Rev 27: 351-363.

Hohmann CF, Berger-Sweeney J (1998). Cholinergic regulation of cortical development and plasticity: new twists to an old story. Perspect Dev Neurobiol 5: 401-425.

$\mathrm{Hu}$ ZT, Yuri K, Ichikawa T, Kawata M (1996). Exposure of postnatal rats to glucocorticoids suppresses the development of choline acetyltransferase-immunoreactive neurons: role of adrenal steroids in the development of forebrain cholinergic neurons. I Chem Neuroanat 10: 1-10.

Hultgårdh-Nilsson A, Querol-Ferrer V, Jonzon B, Krondahl U, Nilsson J (1994). Cyclic AMP, early response gene expression, and DNA synthesis in rat smooth muscle cells. Exp Cell Res 214: 297-302.

Kamphuis PJ, Gardoni F, Kamal A, Croiset G, Bakker JM, Cattabeni $F$ et al (2003). Long-lasting effects of neonatal dexamethasone treatment on spatial learning and hippocampal synaptic plasticity: involvement of the NMDA receptor complex. FASEB J 17: 911-913.

Kamphuis PJGH, Croiset G, Bakker JM, van Bel F, van Ree JM, Wiegant VM (2004). Neonatal dexamethasone treatment affects social behaviour of rats in later life. Neuropharmacology 47: 461-474.

Kawata M, Yuri K, Ozawa H, Nishi M, Ito T, Hu Z et al (1998). Steroid hormones and their receptors in the brain. J Steroid Biochem Mol Biol 65: 273-280.

Khan IY, Lakasing L, Poston L, Nicolaides KH (2003). Fetal programming for adult disease: where next? J Maternal Fetal Neonatal Med 13: 292-299.

Kitraki E, Alexis MN, Papalopoulou M, Stylianopoulou F (1996). Glucocorticoid receptor gene expression in the embryonic rat brain. Neuroendocrinology 63: 305-317.

Klemm N, Kuhar MJ (1979). Post-mortem changes in high affinity choline uptake. J Neurochem 32: 1487-1494.

Kreider ML, Levin ED, Seidler FJ, Slotkin TA (2005). Gestational dexamethasone treatment elicits sex-dependent alterations in locomotor activity, reward-based memory and hippocampal cholinergic function in adolescent and adult rats. Neuropsychopharmacology (in press).

Kreider ML, Seidler FJ, Cousins MM, Tate CA, Slotkin TA (2004). Transiently overexpressed $\alpha_{2}$-adrenoceptors and their control of DNA synthesis in the developing brain. Dev Brain Res 152: 233-239.

Labarca C, Piagen K (1980). A simple, rapid, and sensitive DNA assay procedure. Anal Biochem 102: 344-352.

Lackland DT, Egan BM, Ferguson PL (2003). Low birth weight as a risk factor for hypertension. J Clin Hypertens 5: 133-136.
Lam F, Elliott J, Jones JS, Katz M, Knuppel RA, Morrison J et al (1998). Clinical issues surrounding the use of terbutaline sulfate for preterm labor. Obstet Gynecol Survey 53: S85-S95.

Lau C, Seidler FJ, Cameron AM, Navarro HA, Bell JM, Bartolome J et al (1988). Nutritional influences on adrenal chromaffin cell development: comparison with central neurons. Pediatr Res 24: 583-587.

Lauder JM, Schambra UB (1999). Morphogenetic roles of acetylcholine. Environ Health Perspect 107(Suppl 1): 65-69.

Le Cras TD, Markham NE, Morris KG, Ahrens CR, McMurtry IF, Abman SH (2000). Neonatal dexamethasone treatment increases the risk for pulmonary hypertension in adult rats. Am J Physiol 278: L822-L829.

Lidow MS, Goldman-Rakic PS, Rakic P (1991). Synchronized overproduction of neurotransmitter receptors in diverse regions of the primate cerebral cortex. Proc Nat Acad Sci USA 88: 10218-10221.

Lidow MS, Rakic P (1995). Neurotransmitter receptors in the proliferative zones of the developing primate occipital lobe. J Comp Neurol 360: 393-402.

Limbird LE, Macmillan ST (1981). Mn-uncoupling of the catecholamine sensitive adenylate cyclase system of rat reticulocytes. Biochim Biophys Acta 677: 408-416.

Maccari S, Darnaudery M, Morley-Fletcher S, Zuena AR, Cinque C, Van Reeth O (2003). Prenatal stress and long-term consequences: implications of glucocorticoid hormones. Neurosci Biobehav Rev 27: 119-127.

Matthews SG (2000). Antenatal glucocorticoids and programming of the developing CNS. Pediatr Res 47: 291-300.

Matthews SG, Owen D, Banjanin S, Andrews MH (2002). Glucocorticoids, hypothalamo-pituitary-adrenal (HPA) development, and life after birth. Endocr Res 28: 709-718.

McEwen BS (1992). Steroid hormones: effect on brain development and function. Horm Res 37: 1-10.

Meaney MJ, Diorio J, Francis D, Widdowson J, LaPlante P, Caldji C et al (1996). Early environmental regulation of forebrain glucocorticoid receptor gene expression: implications for adrenocortical responses to stress. Dev Neurosci 18: 49-72.

Meaney MJ, O’Donnell D, Viau V, Bhatnagar S, Sarrieau A, Smythe $J$ et al (1993). Corticosteroid receptors in the rat brain and pituitary during development and hypothalamic-pituitaryadrenal function. In: Zagon IS, McLaughlin PJ (eds). Receptors in the Developing Nervous System, Volume 1: Growth Factors and Hormones. Chapman \& Hall: New York, pp 163-201.

Meyer A, Seidler FJ, Aldridge JE, Slotkin TA (2005). Developmental exposure to terbutaline alters cell signaling in mature rat brain regions and augments the effects of subsequent neonatal exposure to the organophosphorus insecticide, chlorpyrifos. Toxicol Appl Pharmacol 203: 156-168.

Muneoka K, Mikuni M, Ogawa T, Kitera K, Kamei K, Takigawa M et al (1997). Prenatal dexamethasone exposure alters brain monoamine metabolism and adrenocortical response in rat offspring. Am J Physiol 42: R1669-R1675.

Nyirenda MJ, Welberg LA, Seckl JR (2001). Programming hyperglycaemia in the rat through prenatal exposure to glucocorticoids: fetal effect or maternal influence? J Endocrinol 170: $653-660$.

O'Callaghan JP (1993). Quantitative features of reactive gliosis following toxicant-induced damage of the CNS. Ann NY Acad Sci 679: 195-210.

Ortiz LA, Quan A, Zarzar F, Weinberg A, Baum M (2003). Prenatal dexamethasone programs hypertension and renal injury in the rat. Hypertension 41: 328-334.

Owen D, Matthews SG (2003). Glucocorticoids and sex-dependent development of brain glucocorticoid and mineralocorticoid receptors. Endocrinology 144: 2775-2784.

Phillips DIW (2002). Endocrine programming and fetal origins of adult disease. Trends Endocrinol Metab 13: 363. 
Popovik E, Haynes LW (2000). Survival and mitogenesis of neuroepithelial cells are influenced by noradrenergic but not cholinergic innervation in cultured embryonic rat neopallium. Brain Res 853: 227-235.

Qiao D, Seidler FJ, Abreu-Villaça Y, Tate CA, Cousins MM, Slotkin TA (2004). Chlorpyrifos exposure during neurulation: cholinergic synaptic dysfunction and cellular alterations in brain regions at adolescence and adulthood. Dev Brain Res 148: 43-52.

Qiao D, Seidler FJ, Tate CA, Cousins MM, Slotkin TA (2003). Fetal chlorpyrifos exposure: adverse effects on brain cell development and cholinergic biomarkers emerge postnatally and continue into adolescence and adulthood. Environ Health Perspect 111: 536-544.

Reznikov AG, Nosenko ND, Tarasenko LV (2004). Early postnatal effects of prenatal exposure to glucocorticoids on testosterone metabolism and biogenic monoamines in discrete neuroendocrine regions of the rat brain. Comp Biochem Physiol C 138: $169-175$.

Rhodes MC, Seidler FJ, Abdel-Rahman A, Tate CA, Nyska A, Rincavage HL et al (2004a). Terbutaline is a developmental neurotoxicant: effects on neuroproteins and morphology in cerebellum, hippocampus and somatosensory cortex. J Pharmacol Exp Ther 308: 529-537.

Rhodes MC, Seidler FJ, Qiao D, Tate CA, Cousins MM, Slotkin TA (2004b). Does pharmacotherapy for preterm labor sensitize the developing brain to environmental neurotoxicants? Cellular and synaptic effects of sequential exposure to terbutaline and chlorpyrifos in neonatal rats. Toxicol Appl Pharmacol 195 203-217.

Rodier PM (1988). Structural-functional relationships in experimentally induced brain damage. Prog Brain Res 73: 335-348.

Seamon KB, Daly JW (1986). Forskolin: its biological and chemical properties. Adv Cyclic Nucleotide Protein Phosphoryl Res 20: $1-150$.

Seckl JR (2001). Glucocorticoid programming of the fetus: adult phenotypes and molecular mechanisms. Mol Cell Endocrinol 185: $61-71$.

Seckl JR (2004). Prenatal glucocorticoids and long-term programming. Eur J Endocrinol 151: U49-U62.

Shi BT, Rabin SJ, Brandoli C, Mocchetti I (1998). Dexamethasone induces hypertrophy of developing medial septum cholinergic neurons: potential role of nerve growth factor. J Neurosci 18: 9326-9334.

Shinwell ES, Karplus M, Reich D, Weintraub Z, Blazer S, Bader D et al (2000). Early postnatal dexamethasone treatment and increased incidence of cerebral palsy. Arch Dis Child 83: F177-F181.

Simon JR, Atweh S, Kuhar MJ (1976). Sodium-dependent high affinity choline uptake: a regulatory step in the synthesis of acetylcholine. J Neurochem 26: 909-922.

Slotkin TA, Auman JT, Seidler FJ (2003). Ontogenesis of $\beta$ adrenoceptor signaling: implications for perinatal physiology and for fetal effects of tocolytic drugs. J Pharmacol Exp Ther 306: $1-7$.

Slotkin TA, Barnes G, Lau C, Seidler FJ, Trepanier P, Weigel SJ et al (1982). Development of polyamine and biogenic amine systems in brains and hearts of neonatal rats given dexamethasone: role of biochemical alterations in cellular maturation for producing deficits in ontogeny of neurotransmitter levels, uptake, storage and turnover. J Pharmacol Exp Ther 221: 686-693.

Slotkin TA, Lappi SE, Tayyeb MI, Seidler FJ (1991a). Dosedependent glucocorticoid effects on noradrenergic synaptogenesis in rat brain: ontogeny of $\left[{ }^{3} \mathrm{H}\right]$ desmethylimipramine binding sites after fetal exposure to dexamethasone. Res Comm Chem Pathol Pharmacol 73: 3-19.

Slotkin TA, Lau C, McCook EC, Lappi SE, Seidler FJ (1994a). Glucocorticoids enhance intracellular signaling via adenylate cyclase at three distinct loci in the fetus: a mechanism for heterologous teratogenic sensitization? Toxicol Appl Pharmacol 127: $64-75$.

Slotkin TA, Lau C, Seidler FJ (1994b). Adrenergic receptor overexpression in the fetal rat: distribution, receptor subtypes and coupling to adenylate cyclase via G-proteins. Toxicol Appl Pharmacol 129: 223-234.

Slotkin TA, McCook EC, Nemeroff CB, Seidler FJ (1991b). Species differences in $\alpha_{2}$-adrenergic regulation of platelet adenylate cyclase. Res Comm Chem Pathol Pharmacol 72: 259-271.

Slotkin TA, Persons D, Slepetis RJ, Taylor D, Bartolome J (1984). Control of nucleic acid and protein synthesis in developing brain, kidney, and heart of the neonatal rat: effects of $\alpha$ difluoromethylornithine, a specific, irreversible inhibitor of ornithine decarboxylase. Teratology 30: 211-224.

Slotkin TA, Seidler FJ, Qiao D, Aldridge JE, Tate CA, Cousins MM et al (2005). Effects of prenatal nicotine exposure on primate brain development and attempted amelioration with supplemental choline or vitamin C: neurotransmitter receptors, cell signaling and cell development biomarkers in fetal brain regions of Rhesus monkeys. Neuropsychopharmacology 30: 129-144.

Slotkin TA, Windh R, Whitmore WL, Seidler FJ (1988). Adrenergic control of DNA synthesis in developing rat brain regions: effects of intracisternal administration of isoproterenol. Brain Res Bull 21: 737-740.

Smith PK, Krohn RI, Hermanson GT, Mallia AK, Gartner FH, Provenzano MD et al (1985). Measurement of protein using bicinchoninic acid. Anal Biochem 150: 76-85.

Snedecor GW, Cochran WG (1967). Statistical Methods. Iowa State University Press: Ames, Iowa. 593pp.

Trauth JA, Seidler FJ, Slotkin TA (2000). An animal model of adolescent nicotine exposure: effects on gene expression and macromolecular constituents in rat brain regions. Brain Res 867: 29-39.

Trautman PD, Meyer-Bahlburg HFL, Postelnek J, New MI (1995). Effects of early prenatal dexamethasone on the cognitive and behavioral development of young children: results of a pilot study. Psychoneuroendocrinology 20: 439-449.

Tseng YT, Wadhawan R, Stabila JP, McGonnigal BG, Padbury JF (2002). Molecular interactions between glucocorticoid and catecholamine signaling pathways. J Allergy Clin Immunol 110: S247-S254.

Varma DR (1986). Investigation of the maternal to foetal serum concentration gradient of dexamethasone in the rat. $\mathrm{Br} J$ Pharmacol 88: 815-820.

Vatner DE, Asai K, Iwase M, Ishikawa Y, Wagner TE, Shannon RP et al (1998). Overexpression of myocardial $\mathrm{G}_{\mathrm{s} \alpha}$ prevents full expression of catecholamine desensitization despite increased $\beta$-adrenergic receptor kinase. J Clin Invest 101: 1916-1922.

Vickroy T, Roeske W, Yamamura H (1984). Sodium-dependent high-affinity binding of $\left[{ }^{3} \mathrm{H}\right]$ hemicholinium-3 in the rat brain: a potentially selective marker for presynaptic cholinergic sites. Life Sci 35: 2335-2343.

Weinstock M (2001). Alterations induced by gestational stress in brain morphology and behaviour of the offspring. Prog Neurobiol 65: 427-451.

Welberg LAM, Seckl JR (2001). Prenatal stress, glucocorticoids and the programming of the brain. J Neuroendocrinol 13: 113-128.

Whitaker-Azmitia PM (1991). Role of serotonin and other neurotransmitter receptors in brain development: basis for developmental pharmacology. Pharmacol Rev 43: 553-561.

Winick M, Noble A (1965). Quantitative changes in DNA, RNA and protein during prenatal and postnatal growth in the rat. Dev Biol 12: 451-466.

Yeh TF, Lin YJ, Lin HC, Huang CC, Hsieh WS, Lin CH et al (2004). Outcomes at school age after postnatal dexamethasone therapy for lung disease of prematurity. $N$ Engl J Med 350: 1304-1313. 
Zahalka E, Seidler FJ, Lappi SE, Yanai J, Slotkin TA (1993a). Differential development of cholinergic nerve terminal markers in rat brain regions: Implications for nerve terminal density, impulse activity and specific gene expression. Brain Res 601: 221-229.

Zahalka EA, Seidler FJ, Slotkin TA (1993b). Dexamethasone treatment in utero enhances neonatal cholinergic nerve terminal development in rat brain. Res Comm Chem Pathol Pharmacol 81: 191-198.

Zeiders JL, Seidler FJ, Iaccarino G, Koch WJ, Slotkin TA (1999a). Ontogeny of cardiac $\beta$-adrenoceptor desensitization mechanisms: agonist treatment enhances receptor/G-protein transduction rather than eliciting uncoupling. J Mol Cell Cardiol 31: 413-423.
Zeiders JL, Seidler FJ, Slotkin TA (1997). Ontogeny of regulatory mechanisms for $\beta$-adrenoceptor control of rat cardiac adenylyl cyclase: targeting of G-proteins and the cyclase catalytic subunit. J Mol Cell Cardiol 29: 603-615.

Zeiders JL, Seidler FJ, Slotkin TA (1999b). Agonist-induced sensitization of $\beta$-adrenoceptor signaling in neonatal rat heart: expression and catalytic activity of adenylyl cyclase. J Pharmacol Exp Ther 291: 503-510.

Zhou C, Wen ZX, Shi DM, Xie ZP (2004). Muscarinic acetylcholine receptors involved in the regulation of neural stem cell proliferation and differentiation in vitro. Cell Biol Int 28: 63-67.

Zhu Y, Culmsee C, Semkova I, Krieglstein J (1998). Stimulation of $\beta_{2}$-adrenoceptors inhibits apoptosis in rat brain after transient forebrain ischemia. J Cerebral Blood Flow Metab 18: 1032-1039. 